\title{
The Spatial Structure of Lithic Landscapes: the Late Holocene Record of East-Central Argentina as a Case Study
}

\author{
Gustavo Barrientos • Luciana Catella • \\ Fernando Oliva
}

(C) Springer Science+Business Media New York 2014

\begin{abstract}
The aim of this paper is to discuss conceptual and methodological issues related with the archaeological study of lithic landscapes and exemplify the approach with a case study (artifact distribution data from east-central Argentina). A lithic landscape - understood as the co-occurrence, in a given geographic space, of different structural units each one composed by a raw material source and the complete set of unmodified and human-modified pieces of rock extracted from that source and then transported, used, and discarded across the landscape (i.e., a scatter area) — can be modeled using kriging, a geostatistical interpolation tool useful for integrating scattered information into coherent spatial models. The case study allows for the examination and discussion of, on one hand, the relationships between the type and location of the
\end{abstract}

\footnotetext{
G. Barrientos $(\bowtie)$

División Antropología, Facultad de Ciencias Naturales y Museo, Universidad Nacional de La Plata, Paseo del Bosque s/n, B1900FWA La Plata, Argentina

e-mail: barrient@museo.fcnym.unlp.edu.ar

G. Barrientos

Consejo Nacional de Investigaciones Científicas y Técnicas (CONICET), Buenos Aires, Argentina

G. Barrientos $\cdot$ L. Catella $\cdot$ F. Oliva

Centro de Estudios Arqueológicos Regionales (CEAR), Facultad de Humanidades y Artes, Universidad Nacional de Rosario, Entre Ríos 758, S2000CRN Rosario, Argentina

L. Catella

e-mail: catellaluciana@hotmail.com

F. Oliva

e-mail: fwpoliva@gmail.com

L. Catella

División Arqueología, Facultad de Ciencias Naturales y Museo, Universidad Nacional de La Plata, Paseo del Bosque s/n, B1900FWA La Plata, Argentina

F. Oliva

Facultad de Humanidades y Artes, Universidad Nacional de Rosario, Entre Ríos 758,

S2000CRN Rosario, Argentina
} 
sources and the size and shape of the respective scatter areas and, on the other, the reciprocal relationships between different raw materials and sources. It is concluded that a proper description of the spatial structure of a lithic landscape is the needed baseline from which to evaluate different explanatory models. Such models should take into account different sets of initial conditions and generative mechanisms, in order to cope with the pervasive problem of equifinality.

Keywords Lithic landscapes $\cdot$ Raw material sources · Artifact distributions - Geostatistics · East-central Argentina · Late Holocene

\section{Introduction}

A spatial structure can be conceptualized as a patterned arrangement of entities in an $n$ dimensional space. From a geographic point of view, the term usually refers to the organized distribution of objects on, or immediately beneath, the surface of the earth. Spatial structures exist because geographic space (i.e., macroscopic, large-scale space; Jiang 2010) is not homogeneous but composed of a set of variously distributed unique places and features (Elissalde and Saint-Julien 2004). Indeed, geographic spaces tend to be heterogeneous and structured, with such qualities emerging from both deterministic and stochastic processes. At the spatial scales at which human social or population phenomena usually occur (micro-, meso-, and macroscales; Delcourt and Delcourt 1988; Dincauze 2000), the geographic space is heterogeneous relative to many significant objective and subjective, intrinsic and extrinsic variables, like distribution, diversity, density, predictability, availability, accessibility, attractiveness, or yield of a resource. In the case of prehistoric hunter-gatherer populations, the distribution, availability, accessibility, quality, and exploitability of lithic raw materials (Ataman et al. 1992; Bamforth 1986; Elston 1992; Kuhn 1991; Wilson 2003, 2007a, b, 2011) were likely major socioecological factors either constraining or allowing the spatiotemporal material expression of their aggregated (i.e., individual plus collective) behaviors. On the long run, the cumulative effects of spatiotemporal behaviors (i.e., individual and collective behaviors that manifest at different successive points in space and time) involving the procurement, manufacture, transport, use, and discard of lithic materials provide the structural features of what we can call a lithic landscape ( $c f$. Gould and Saggers 1985 , p. 124). Such a landscape can be ideally thought as the spatial cooccurrence of different structural units (i.e., the "building blocks" of the larger structure that is the lithic landscape), each one composed by two principal elements, a raw material source and a surrounding scatter area, the latter comprising the complete set of unmodified and human-modified pieces of rock extracted from that source and then transported, used, and discarded across the landscape. Lithic landscapes can be archaeologically approached using a variety of sampling, analytical, and visualizing techniques. The construction of reliable models about the spatial structure of such landscapes should be the first step of any research aimed at understanding, at some specified scale, the relationships between the organization of the archaeological record (our subject matter) and the organizing dynamics that operated in the past (our explanatory variables). Those dynamics primarily include, at the ecological time, the successive choices of social actors obeying to certain logics (Clark and Scheiber 2008; Elissalde 
and Saint-Julien 2004), although it is expected that, on the long run (i.e., at evolutionary time), the overlapping and commingling effects of a variety of such logics and of other factors - e.g. taphonomic and, at a later stage, archaeological (sampling and analysis) will hamper a straightforward lecture of the material and relational evidence in terms of identifiable systemic - mainly behavioral-processes (Barton et al. 1999, 2002, 2004; Bailey 1981, 2007; Burger et al. 2008; Holdaway et al. 2008, 2012; Shott 2006; Wandsnider 1992, 1998; Wilson 2007b; Zvelebil et al. 1992).

Within this context, the aim of this paper is twofold: first to set the background for the study of the spatial structure of lithic landscapes, discussing - in a programmatic waythe theoretical, methodological, and epistemological foundations for its archaeological study; second, to exemplify the approach to the description (i.e., spatial modeling) of lithic landscapes with a case study involving artifact distribution data from east-central Argentina. The detailed discussion of many specific aspects of the lithic record from this region is out of the scope of this paper and is addressed elsewhere (Catella 2014). However, it is expected that the data and analyses presented in this exploratory study will illustrate well both the strengths and limitations of the advocated approach, thus encouraging future theoretical, methodological, and empirical research on the subject.

\section{What Is a Lithic Landscape?}

\section{A Concise Definition}

Among the many existing archaeological perspectives on landscape, in this paper, we adopt the one that considers it an efficient means of representing and understanding spatiotemporal variability in the archaeological record (Holdaway et al. 2012). The active incorporation of space in the analysis allows for the integration of a diversity of datasets and for a better approach to the processes that produce, at different scales, the kind of patterned variation whose documentation and explanation constitutes one of the core objectives of archaeological research (Binford 2001; Darvill 2008; Kelly and Thomas 2009).

From this perspective, a lithic landscape would be conceptualized as the co-occurrence, in a given geographic space, of different structural units composed by two principal elements: a raw material source and an associated scatter or strewn area. The latter comprise the spatial distribution of both unmodified and human-modified pieces of rocks, either directly or indirectly (Féblot-Augustins 2009) procured from that source (Fig. 1). This is a different and a more inclusive definition of the term than that first introduced in the literature by Gould and Saggers (1985). For these authors, a lithic landscape refers solely to the availability and physical distribution of different raw materials in a region (Gould and Saggers 1985, p. 124), thus being equivalent in meaning to the terms "regional lithic resource base" (Ericson 1984) and "lithic terrane" (Elston 1992).

\section{The Components of a Lithic Landscape}

Lithic raw materials can come from either point or diffuse sources. A point source is a localized and a more or less isolated primary (e.g., a bedrock exposure or outcrop) or secondary (e.g., a glacial, stream, beach, and talus slope deposit) procurement place (the "primary" and "secondary" character of sources coincides here with the definition 
a Lithic Sources

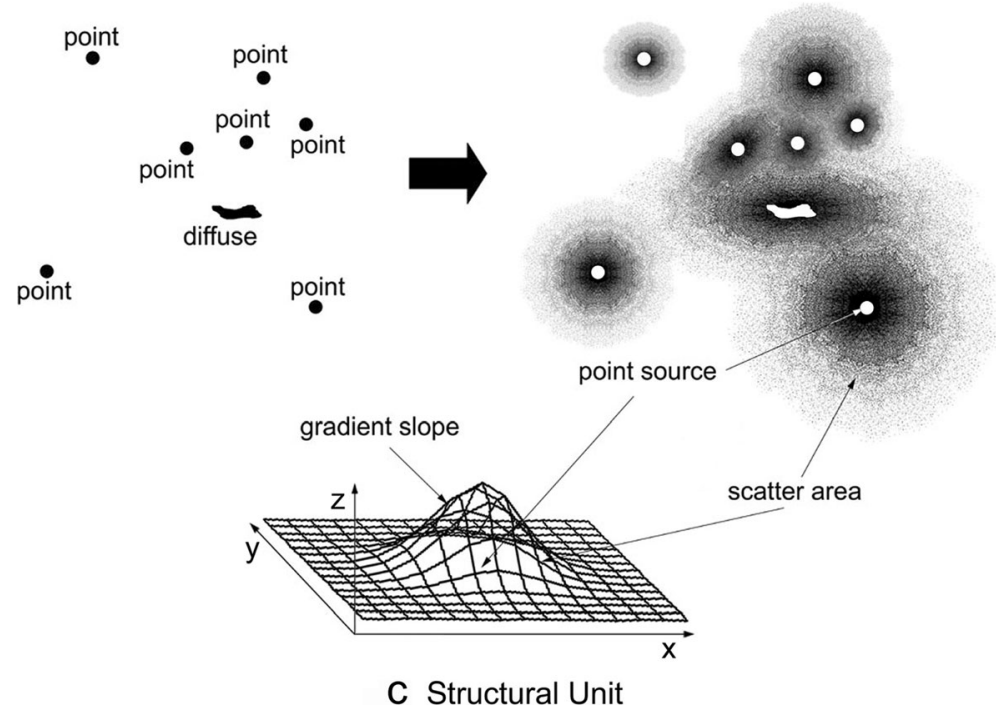

Fig. 1 Schematic representation of the structure of a lithic landscape. a Point and diffuse sources of a particular raw material; $\mathbf{b}$ sources and scatter areas; $\mathbf{c} 3 \mathrm{D}$ view of a structural unit in which $x$ and $y$ represent space and $z$ the value of a response variable (e.g., raw counts, percentages, or frequency data)

of "primary" and "secondary" geological contexts; Luedtke 1979, p. 745; for a different and less usual definition of primary and secondary lithic sources, see McCoy et al. 2010, p. 174). A diffuse source (Bakken 2011) is a very extensive (i.e., ranging from the local to the regional domains) and a difficult-to-delimit procurement area, in which toolstones are available in either a primary (e.g., a large-scale geologic formation) or a secondary (e.g., a geographically extended gravel mantle, or a glacial drift deposit) geological context.

While the concept of source is rather unproblematic, with a large amount of literature dealing with the subject (e.g., Ataman et al. 1992; Bakken 2011; Bamforth 2006; Blades and Adams 2009; Charlin 2009; Colombo 2013; Elston 1992; Ericson and Purdy 1984; Franco and Borrero 1999; Gould and Saggers 1985; Ingbar 1994; Kuhn 1991; Luedtke 1979; Topping and Lynott 2005; Torrence 1986, 1989; Wilson $2007 b, 2011)$, the introduction of the concept of scatter area requires some justification. The basic premise lying behind the concept is that the operation of any system based on the exploitation of lithic resources will produce - at different temporal scales - a spatial rearrangement of rocky fragments either under the form of raw materials (i.e., unmodified chunks/hunks/sheets/chips; Greber 1976) or artifacts (i.e., cores, tools, and debitage) with the latter in turn potentially serving, due to the extractive nature of lithic technology, as raw materials for further artifact production (see, among others, Collins 1975; Ericson 1984; Kelly 1988; Kuhn 1991; Nelson 1991). This implies that there is always a spatial transfer of rocks from an exploited source to one or many other locations across the landscape as the result of the operation of such a system (e.g., Féblot-Augustins 2009; Renfrew 1972). The implied transport of unmodified and human-modified stones can be very short (less than $1 \mathrm{~m}$ ) or very long (of the order of hundreds or even thousands of kilometers). The spatial distribution of all the unmodified rocks and artifacts deposited on or beneath the earth's surface and whose 
raw materials come from a single source defines a scatter or strewn area. This term ought not to be confused with that of "lithic scatter," which is defined as a type of archaeological site (i.e., a microscalar phenomenon) consisting in a surface distribution of lithic artifacts primarily resulting from the disturbance of original depositional contexts by natural forces and/or human agency (Chartkoff 1995, p. 29; English Heritage 2000, p. 2).

It is important to note that we never have neither a direct nor a complete access to the nature of a scatter area. Just like in the case of settlement patterns-where archaeologists do not have access to the full set of places used by an organized group of people at some specified time period in the past but only to a limited number of such places, i.e., to a "remnant settlement pattern" from which some properties of the "full settlement pattern" ought to be inferred (Rouse 1972, p. 97) —all the characteristics of a scatter area have to be modeled from archaeological evidence.

Ideally, a scatter area around a raw material source can be regular (i.e., nearsymmetric) or irregular in shape (Ericson 1977). Its extension can be variable, but usually comprising sizes belonging to a meso- or a macroscale spatial domain (see Delcourt and Delcourt 1988; Dincauze 2000). An important property of a scatter area is gradient, which designates the usually (but not exclusively) monotonic decrement (Renfrew 1972, 1975, 1977; Renfrew et al. 1968; cf. Ortega et al. 2014) - alternatively called fall-off or distance decay — in spatial density, size, weight, or frequency of lithic artifacts from the raw material source to the outer limits of the strewn area (Fig. 1). This is a well-known pattern affecting different commodities and products that emerges because the costs of transport usually increase with increasing distance from the source. ${ }^{1}$ Such a gradient can be smooth or steep depending on factors like mobility patterns, the quality of the raw material, the nature of the access to the commodity (direct o indirect via exchange or trade), and the spatial proximity and/or competition ${ }^{2}$ - in terms of human needs, preferences, and strategic/tactical/operational decision rules - between two or more raw material sources (Biró and Regenye 1991; Brantingham 2006; Elston 1992; Ericson 1977; Hodder and Orton 1976; Kooyman 2000; Reid 1986; Torrence 1986; Wilson 2007b).

It can be predicted that, around an isolated source and over a featureless isotropic plain, the corresponding scatter area will take - on the long run - a round shape with a radially symmetric distribution of gradient. This is so because the successive movements (and the consequent transport and discard of toolstone) from that source to outer areas will occur with equal probability in all directions, a process that can be easily

\footnotetext{
${ }^{1}$ People, of course, do not necessarily make decisions based on cost considerations. However, the probability of transporting a certain quantity of raw materials under the form of artifacts or unmodified pieces of rock (objects with mass, and hence with weight) decreases as a function of the distance from the source, irrespective of the conscious or unconscious decisions of the actors. In the short term, we may observe significant deviations from the expected distance decay pattern, but on the long run, the cumulative distribution of lithics across a region resulting from a large number of events of transport, use, and discard will tend to statistically manifest the influence of this natural organizing principle.

${ }^{2}$ When we speak of "competition" between rocks, we are using a figurative expression to depict a situation in which two or more toolstones, whose sources are spatially close to one another, have a differential probability of being used by humans. Such a probability depends on the intrinsic properties of the rocks and of their sources but, above all, on cultural preferences and strategic/tactical/operational decision rules applied by people. With the same or nearly the same meaning, the term has already been used by several authors (e.g., Biró and Regenye 1991; Laylander 2005; Shelford et al. 1982; Tripcevich 2007).
} 
simulated with random walks (Brantingham 2006; Hodder and Orton 1976). In most real situations, however, there are a number of factors that may create deviations from an ideal symmetric distribution (Haggett 1965; von Thünen [1826] 1966). Foremost among them is the presence of competing or alternative raw material sources and of landscape features that modify, either by increasing (e.g., upland areas of difficult terrain) or diminishing (e.g., navigable rivers, corridor areas), transport costs (Fig. 2).

\section{The Palimpsest Nature of Lithic Landscapes}

Rocks from two or more sources can travel together (i.e., integrating specific toolkits) or separated, but however, they can be discarded, cached, or lost at the same place in a single or different events (Barton et al. 1999, 2002, 2004; Wandsnider 1992, 1998; Wilson 2007b; Zvelebil et al. 1992). Rocks from different sources can accumulate at any given point in space at different rates, then producing a differential representation of each toolstone class. This is a process controlled by the influence of many different factors primarily related to (a) the rocks themselves (e.g., regional abundance, mechanic properties, size, shape, and location of the outcrops or secondary deposits; Ataman et al. 1992; Brantingham et al. 2000; Ingbar 1994; Kuhn 1991; Wilson 2007b); (b) human organization and demography (e.g., geographic distribution of people and population density values, kind and degree of mobility; Ataman et al. 1992; Binford 1980; Brantingham 2003, 2006; Chatters 1987; Jeske 1992); and (c) culturally inherited preferences and decision rules related with different aspects of the organization of technology (e.g., distance between loci of human activity and raw material sources, portability of the different products of a particular reduction sequence, rock quality judgments, design constraints and possibilities, degree to which a specific toolstone is laden with cultural or prestigious associations; management strategies of lithic resources, including the control on the access to the sources, the transport and caching of chunks or artifacts, the exchange or trading of lithic materials, levels of planning, provisioning strategies; e.g., Amick 1996; Bamforth 1986; Bamforth and Woodman 2004; Binford 1973, 1977, 1979; Brantingham 2003, 2006; Carr and Bradbury 2011;

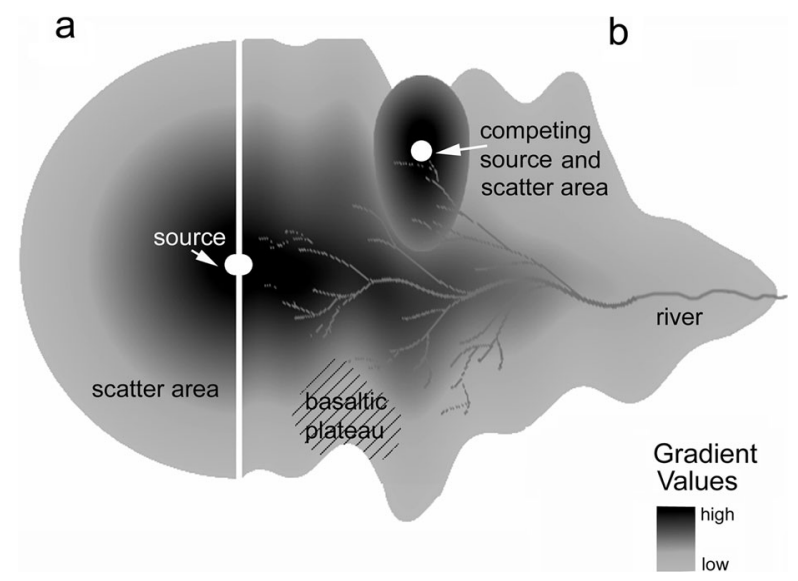

Fig. 2 2D representation of a structural unit of an ideal lithic landscape. $a$ Round scatter area with a radially symmetric distribution of gradient around an isolated source and over a featureless isotropic plain; $b$ irregular scatter area in a heterogeneous landscape surface 
Chatters 1987; Collins 1975; Elston 1992; Graf 2010; Hodder and Orton 1976; Ingbar 1994; Kelly 1988; Khun 1995, 2004; Nelson 1991; Renfrew 1977; Roebroeks et al. 1988; Tripcevich 2007; Wilson 2007a, b, 2011). In archaeological time, however, the effects of all these factors operating at the systemic level (i.e., in the short to medium term) usually clump together forming inextricable palimpsests (e.g., Aston and Rowley 1974; Bailey 1981, 2007; Binford 1980, 1981; Holdaway et al. 2008; Ferring 1986; Wandsnider 1998). Since its popularization by Binford (1981), the notion that the palimpsest effect constitutes one of the main structural properties of the archaeological record has become firmly established, being one of the fundamental concepts of time perspectivism (Bailey 1981, 2007; Holdaway et al. 2008). A palimpsest is the natural consequence of the accumulation of materials deposited, at different rates and at different scale domains (i.e., micro-, meso-, and macroscale, roughly corresponding to the local, regional, and supra- or macroregional levels, respectively), in the course of multiple successive episodes occurred at both particular activity areas and transit corridors or paths connecting such areas, whose spatial position changes over time. From the viewpoint of time perspectivism, the one that we favor, palimpsests are conceived not as a kind of "noisy" structure that needs to be dissected and disentangled, but as the consequence of processes that create - at different scales-temporospatial patterning in the archaeological record (Holdaway et al. 2008). An archaeological approach to lithic landscapes thus involves the problem of extracting meaningful information (in terms of the understanding of long-term processes) from the cumulative patterning of the material correlates of human behavior, an issue that is addressed in the next section of this paper.

\section{The Archaeological Study of Lithic Landscapes}

\section{Descriptive/Interpretive Modeling}

\section{The Regional Lithic Resource Base and the Problem of Sourcing}

The size of the geographic space at which the structure of lithic landscapes ought to be modeled, ranges from the mesoscale to the macroscale (i.e., regional to supraregional level of analysis). Within such spaces, the assessment of the absolute and relative position of two kinds of elements is crucial, namely (i) the potential and actual sources of lithic raw materials, and (ii) the unmodified and human-modified pieces of rock coming from those sources and whose presence in specific points of the landscape cannot be explained by forces other than human agency. This presupposes the carrying out of systematic activities aimed, first, at assessing the structure of the regional lithic resource base (sensu Ericson 1984) and then at sourcing-i.e., the act of establishing a hypothetical linkage between (a) single isolated elements or set of elements and (b) variously defined raw material sources (Bishop 2012, p. 579).

The building of reliable models about the structure of a regional lithic resource base is a complex undertaking that requires the integration of multiple sources of information (e.g., geological, geomorphological, petrographic, geochemical, archaeological), the execution of different activities (e.g., bibliographic and cartographic search, field survey, remote sensing, laboratory analysis, interdisciplinary interaction), and the 
acquisition, administration, analysis, and graphical representation of a high volume of spatial data. The resulting model — which is always provisional and perfectible — can have, at different scales, a various degree of detail and resolution due to insufficient or imperfect information. In general, such a model is based on actualistic information, and there is no simple way to assess the past availability, abundance, form, quality, and exploitability of lithic resources, particularly for environments that have experienced significant geomorphological change (Phillips 2011). Despite this, it is clear that all effort invested in assessing the structure of the regional lithic resource base is worthy since it constitutes a major factor influencing the way stone tools were produced, transported, used, maintained, and discarded (Andrefsky 2009).

The knowledge about raw material sources is just a part of the problem, to the extent that it is almost useless unless we are able to establish clear, albeit hypothetical, connections between sources and products (i.e., artifacts recovered at different locations across the landscape). Several methods exist to accomplish this task, being the visual assessment of hand specimens the commonest sourcing practice everywhere (Andrefsky 2009; Elburg and van der Kroft 2006; Odell 2004). This is so because more precise options, like petrographic (e.g., thin-section microscopy, X-ray diffraction or XRD) or geochemical methods (e.g., acid digestion and laser ablation inductively coupled plasma mass spectrometry or AD-ICP-MS and LA-ICP-MS, respectively), still remain difficult to implement at large scale due to a number of reasons (e.g., limited time and budget, restricted access to appropriate facilities, lack of specific training; see discussion in Odell 2004, pp. 41-42). However, despite the many advances in sourcing methodology, it must be remembered that not all toolstone can be sourced with equal confidence. There seems to be a close inverse relationship between the degree of complication of the rock formation process (including its duration and spatial extension) and the reliability of sourcing using geochemical techniques (e.g., obsidians are more confidently linked to sources than cherts or quartzites; Andrefsky 2009, pp. 7980; $c f$. Pitblado et al. 2013). In practice, all of these factors cause that, in a given region, a significant portion of the lithic assemblages recovered at archaeological sites can only be loosely linked with specific sources or cannot be sourced at all (Elburg and van der Kroft 2006). This is a major, yet unresolved issue with which archaeologists have to deal in more creative ways - beyond and besides technological sophistication - than those that are currently being used in studies of lithic raw material exploitation. In this sense, the spatial modeling of lithic landscapes can help, to some extent, to establish hypothetical connections between assemblages and sources as it will be shown later in this paper.

\section{Artifact Distribution Data}

Regarding the spatial distribution of artifacts, two basic theoretical assumptions of landscape archaeology (broadly defined here as the archaeological subfield that addresses the issue of how past people have consciously and unconsciously shaped, for a variety of reasons, the land around them; Fennell 2010, p. 1; Hu 2011, pp. 80-81) are that human behavior has a rather continuous expression across space (Foley 1981, p. 13) and that their material products are consequently distributed in a more or less continuous fashion on the surface of the earth (Banning 2002, p. 15; Ebert and Kohler 1988, p. 143; Foley 1981, p. 13; Robins 1997, p. 26). The assumption of a rather 
continuous expression (both immaterial and material) of human behavior, particularly across space, is the main tenet of off-site or distributional archaeology (sensu Foley 1981; Ebert 1992). Individual and collective behaviors manifest themselves in a continuous (in the sense of nondiscrete) way both in space and in time. The material expression of such behaviors also tends, especially in the medium to long term, to be distributed more or less continuously (though with a remarkable variation in density) over the surface of the earth.

The survey strategy advocated by distributional archaeology-simple or stratified random sampling of the surface distribution of artifacts across large geographic spaces (Belardi 1992; Belardi et al. 1992; Borrero et al. 1992; Dunnell and Dancey 1983; Ebert 1992; Ebert and Kohler 1988; Foley 1981; Thomas 1975)_-seems the most appropriate choice for data acquisition aimed at building continuous spatial models of lithic landscapes. However, this sampling approach can only be successfully implemented in regions of high archaeological visibility, which is greatest in areas of low/ slow sedimentation, high deflation, and low vegetation cover. In regions characterized by higher rates of sedimentation, lower rates of soil erosion, and lower surface visibility due to dense ground cover, most of the survey effort at the meso- or macroscale is typically allocated to the searching of sites by nonprobability means (e.g., convenience, opportunistic, or emergent sampling; Patton 2002). This occur despite of the theoretical/methodological awareness of the involved archaeologists and obeys to the fact that subsurface discovery techniques like shovel testing and ground penetrating radar assessment (GPR) are virtually impracticable at a higher-than-local level.

While relying on primary or original data may be desirable in order to model a lithic landscape - irrespective of the sampling procedure deployed in each case - it is highly unlikely that any single study can cover a space of the magnitude in which it really makes sense to speak of such an entity (i.e., meso- to macroscale domains). As a consequence, the analysis of secondary data (i.e., a research strategy which makes use of preexisting data for the purposes of investigating new questions or verifying previous studies; Heaton 2004, p. 16) is usually imposed as a necessity, not a choice.

The fact that quantitative and distributional data may come from a heterogeneous combination of survey strategies deployed at different times by different research teams (i.e., the authors of the original reports) seems, at first glance, a limitation to the quality of data available to model lithic landscapes. However, if conveniently and appropriately filtered, secondary data can be very valuable to the extent that they provide effective means of approaching large-scale phenomena, applying new research questions, and gaining new insights and deeper understanding on old problems at a relatively low cost, measured in terms of time, effort, and loss of information (Andrews et al. 2012; Atici et al. 2013).

\section{Spatial Analysis and Modeling}

Assessing the spatial structure of a specific lithic landscape heavily depends on the ability to manage a great deal of geographic information relative to the location of raw material sources (both primary and secondary), archaeological sampling units, relevant landscape features, and response variable values (e.g., absolute or relative frequency, density, weight). Geographic information systems (GIS) are the natural tools to aid in this task. A GIS integrates hardware and software for capturing, managing, analyzing, 
and displaying different forms of geographically referenced information in search for relationships, patterns, and trends in data. It is, and has been for the last 20 years or so, a much used tool to map and analyze the spatial distribution of archaeological materials (Conolly and Lake 2006; Ebert 2004; Verhagen and Whitley 2012) across and along archaeological landscapes.

Among the many analytical devices incorporated into modern GIS is geostatistics, a multipurpose set of tools used for characterizing spatial variation. Geostatistics deals with the problem of how to make reliable predictions of sampled attributes at unsampled locations from sparse data (Burrough 2001) and is based on the principle of spatial dependence or autocorrelation, which establishes that observations close in space tend to be more similar than those further apart (i.e., the so-called first law of geography; sensu Tobler 1970; see also Lloyd and Atkinson 2004, p. 151; Miller 2004, p. 285). A prominent procedure in geostatistics is interpolation, which is the estimation of the value of a variable at an unmeasured location from observed values at surrounding locations. Interpolation is a method of constructing new data from a discrete set of known data points, enabling the translation of sampled point data into continuous surfaces (Conolly and Lake 2006; Hodder and Orton 1976; Lloyd and Atkinson 2004; Miller 2004). The examination and analysis of continuous surfaces - a procedure that already has a long history in archaeology (e.g., Biró 1998; Biró and Regenye 1991; Ericson 1977; Findlow and Bolognese 1982; Hodder and Orton 1976)-makes more intelligible the spatial information recovered from relatively few, scattered, and unevenly distributed sampling locations.

The geostatistical interpolation tool is kriging, a group of techniques that uses semivariogram (i.e., a two-point statistical function that describes the decreasing correlation between sample values as spatial separation between them increases) to express the spatial variation in data. Technically defined, kriging is an optimal interpolation method based on regression against observed $z$ values of surrounding data points, weighted according to spatial covariance values. The kriging techniques offer a number of output surface types like prediction, prediction standard error, quantile, and probability maps (Johnston et al. 2001), which are major features that distinguish them from deterministic methods for spatial interpolation like inverse distance weighting (IDW) and splines (Azpurua and Dos Ramos 2010; Burrough and McDonnell 1998; Villatoro et al. 2008). Originally introduced in the archaeological literature by Zubrow and Harbaugh (1978), kriging methods have been used in recent years to represent artifact distribution data at different spatial scales and for different purposes (e.g., Aldenderfer 1998; Bevan and Conolly 2009; Harro 1997; Lloyd and Atkinson 2004; Mullett 2009, 2012; Skarbun and Frank 2011).

In order to illustrate the power of kriging to generate reliable models of an underlying spatial structure, we performed a set of informal (i.e., not statistically validated) simulations varying the number and distribution of sampling units superimposed to an ideal graphic depiction of a lithic landscape (Fig. 3). In such representation, different shades of gray symbolize different values of a variable (e.g., raw counts) measured on artifact samples made with a single raw material coming from eight sources. In our ideal model, there is a continuous monotonic decrease in absolute frequency values from the source to the outer limits of the surrounding scatter area. In the first simulation, the sampling units $(n=437)$ were arranged in a regular grid, whereas in the second one, a lesser number of sampling units $(n=154)$ were irregularly distributed. In both cases, 
the data collected from each sampling unit were entered into a spreadsheet and analyzed with the use of ArcGIS 9.3, allowing for the creation of a continuous interpolated surface (prediction map) applying kriging. Figure 3 shows that, in the case of a regular and uniform distribution of a great number of sampling units, the surface map generated by kriging reveals very well the underlying structure of the lithic landscape. By contrast, in the case of a lesser number of irregularly distributed sampling units, the corresponding surface map allows us to glimpse in a somewhat distorted way - something like through a frosted glass - the spatial configuration of the underlying structures. Despite this fact, it is significant that the resulting surface is still informative about the main features of the target lithic landscape. This is remarkable since, in most real-world situations, it is highly likely that both the number and distribution of sampling units will resemble the second rather than the first simulated example.

It has been experimentally shown (Milillo and Gardella 2005) that, with few data points, IDW yield better results than kriging in terms of providing spatial models that capture more details from an underlying image. However, as it was already mentioned, kriging has many comparative advantages over other interpolation methods (e.g., built-
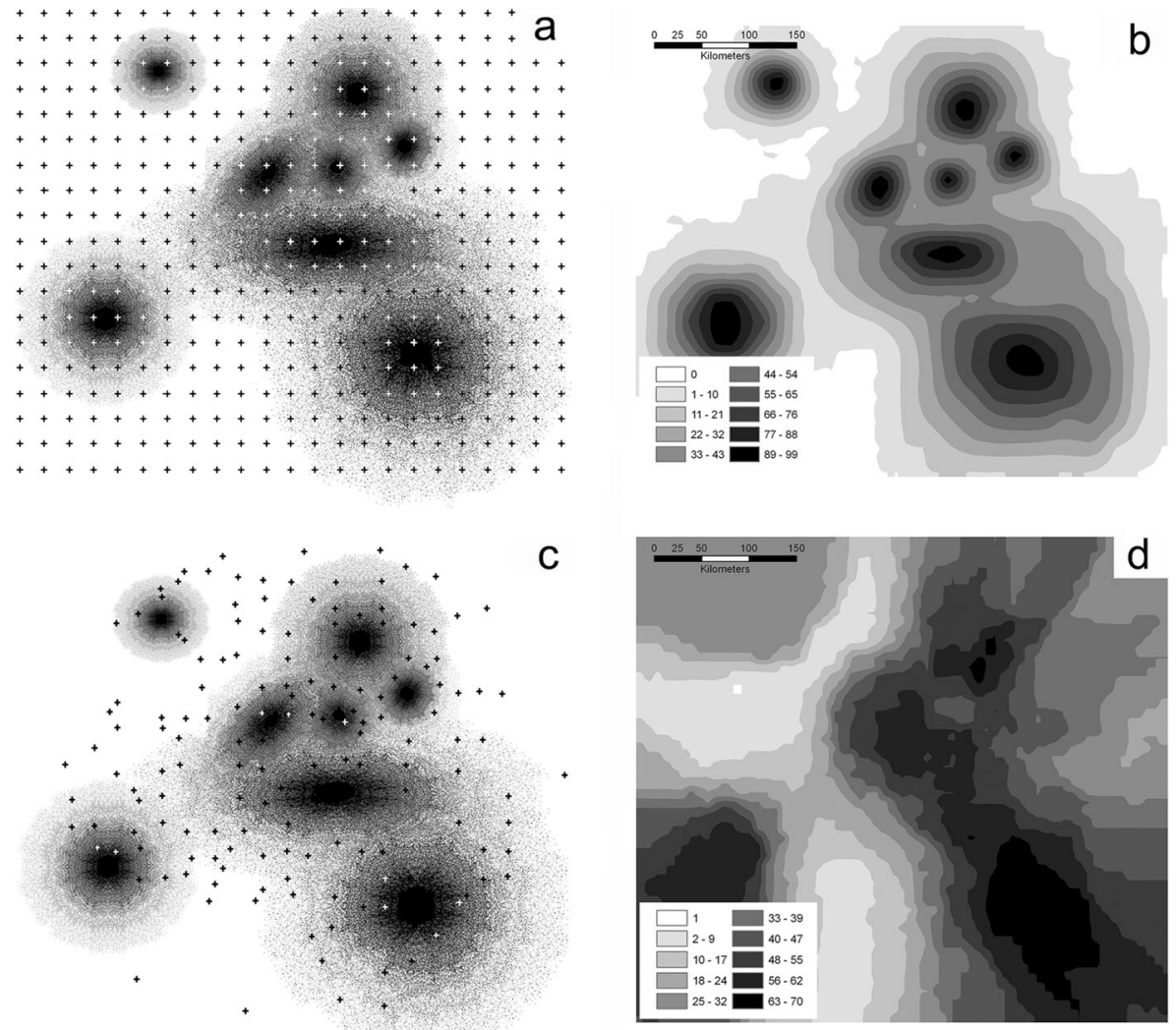

Fig. 3 The structure of a simulated lithic landscape modeled by means of geostatistic interpolation (kriging); a 437 sampling units arranged in a regular grid; b spatial model (continuous surface map) constructed with data obtained from a; c 154 irregularly distributed sampling units; d spatial model (continuous surface map) constructed with data obtained from $\mathbf{c}$ 
in error analysis; adjustments for subtle differences in value over short distances in order to smooth plots; control of redundancies in the covariance matrix and of clustering in data points) that make it the better available option under most circumstances.

\section{Lithic Landscape Models and Their Value}

A last but key issue to be discussed here concerns the value that the modeling of regional lithic landscapes may have in relation with the degree of existing knowledge about the raw materials represented in sources and lithic assemblages as well as the link we can establish between georeferenced artifacts and specific raw material sources (i.e., sourcing). In any given region, the knowledge about the lithic resource base for each specific toolstone - in terms of kind, quantity, distribution, and geochemical fingerprinting of sources - can be quite diverse: while for some, it can be very high, for others, it may be very low or even nonexistent. In the case of artifact assemblages, the information about intraclass and interclass diversity and variability of the raw materials represented can also be very different in terms of grain and resolution. Finally, the hypothetical linkage established between single isolated artifacts or set of artifacts and specific raw material sources can have different degrees of probability depending on factors such as the nature of the toolstone and the sourcing technology used in each case.

The formal relationships between the different degree of knowledge about the variability of the raw materials represented in both the sources and lithic assemblages and the relative value of the spatial models of lithic landscapes are shown in Fig. 4. Scenario A (- ) depicts a situation where there is scarce information about both the variability of one or many toolstone classes represented in lithic assemblages across the regional space and the size, accessibility, localization, and quality of their likely or actual sources. In this case, the spatial model of the lithic landscape-whose primary value is exploratory rather than conclusive-has the potential to contribute to the formulation of working hypotheses about source localization, thus helping to planning

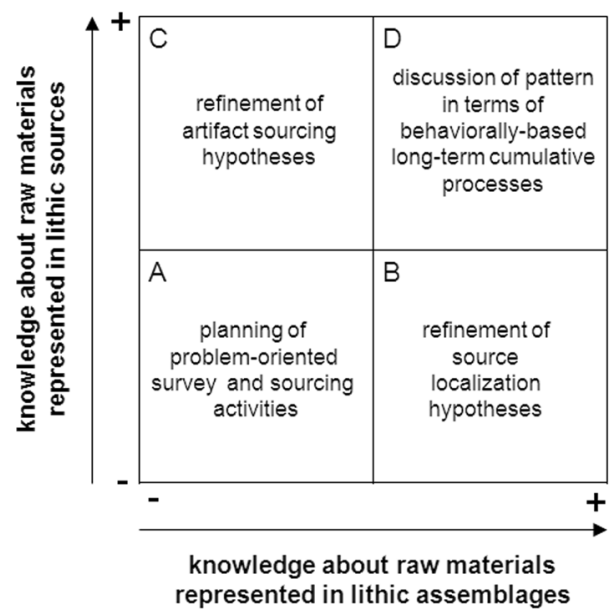

Fig. 4 Formal relationships between the different degree of knowledge about the raw materials represented in both the sources and lithic assemblages and the relative value of the spatial modeling of lithic landscapes 
problem-oriented surveys and sourcing activities. Scenario B $(+-)$ portrays a case where the entire range of variability of one or many toolstone classes represented in lithic assemblages is well known, but the knowledge about the localization of their likely or actual sources is incomplete. In this case, the model has the potential to contribute to the refinement of source localization hypothesis. Scenario $\mathrm{C}(-+)$ typifies the situation in which the knowledge about the characteristics of the regional lithic resource base is good, but the information about the variability of one or many toolstone classes represented in lithic assemblages is incomplete. In this case, the model may help to refine hypotheses about the likely provenience of specific artifacts or set of artifacts. Scenario $4(++)$, finally, depicts a situation in which the knowledge about both the variability of one or many toolstone classes represented in lithic assemblages and the localization and characterization of their actual sources is high. In this case, the model would be reliable enough to allow the discussion of spatial patterning mainly in terms of behaviorally based, long-term cumulative processes.

Synthesizing, we can say that the spatial modeling of lithic landscapes has a heuristic value in the sense of suggesting ways in which further research may profitably be conducted. Its potential to deal with data of different quality makes it a versatile tool that can be used to integrate information at different stages of the research, allowing for the generation and testing of hypotheses concerning to both source localization and spatial structure of the scatter areas.

\section{The Explanation of Patterns}

Coping with Equifinality and Long-Term Processes in the Archaeological Explanation of Patterns

The wide-scale patterned distribution of lithic artifacts, as revealed by our spatial models, needs to be explained in terms of their generative mechanisms, i.e., those structures, forces, or tendencies operating at the deepest level of reality, which are the intransitive objects of scientific enquiry (Bhaskar 1975). At this point, the question is, what kind of explanation should we prefer? Among the early philosophers of explanation, there was a broad consensus that all explanation is, in principle, a causal one (e.g., Salmon 1984) and that the building of a universal theory of scientific explanation is a desirable, realizable, and legitimate goal (French and Saatsi 2011). Today, a multiplicity of accounts of explanations exists - some of them even adopting a noncausal form (e.g., Nerlich 1979; Sober 1983; cf. Skow 2013; Strevens 2008)-partially as a consequence of the increasing awareness among philosophers and scientist alike, that each field of enquiry has its own explanatory goals and styles of knowledge building (French and Saatsi 2011; Woodward 2011). Regarding the explanation of the structural aspects of lithic landscapes, we should choose, among the available alternatives, the one that better fits our needs when trying to cope with an insidious problem in spatial analysis - and in archaeological inference in general (Lyman 2004; Rogers 2000) - that is, equifinality in long-term processes (von Bertalanffy 1950; Driesch 1929).

Two or more processes can be "...called equifinal if they produce outcomes that are [...] similar enough that current statistical methods have difficulty distinguishing between them" (Rogers 2000, p. 721). In our context, equifinality is the probability 
that any single pattern of artifact distribution would be equally caused by different spatial processes (Gibbon 1984, p. 244). Notwithstanding the fact that equifinality is recognized as posing a serious quandary for archaeological explanation, archaeologists in general have yet not addressed the problem with due interest and concern (Lyman 2004, p. 25; for exceptions in lithic studies, see Hodder and Orton 1976, pp. 127-154; Ortega et al. 2014, p. 465; Renfrew 1977, pp. 85-86; Shott 2010, pp. 327-328; Stark and Garraty 2010, pp. 40-41).

From a perspective more centered in the interpretation and explanation of the archaeological record rather than in the inferential reconstruction of ancient dynamics (Holdaway et al. 2008, p. 111), past processes along with other contemporary factors have, in archaeological inquiry, an explanatory role rather than the role of subject matter (Teltser 1995, p. 3). Within this framework, the approach to the explanation of the patterned distributions of lithic artifacts should be probabilistic (Brantingham 2003, 2006; Ingbar 1994) and plural. This implies that insofar any specific pattern can be generated by a potentially infinite number of mechanistic models (Premo 2010, pp. 3134; Turchin 2003, p. 18; 2006, p. 454), we must construct many of such models (preferentially of the simulative type, which can be considered as particular applications of the experimental method; Madella et al. 2014, p. 252) based on differing assumptions about the underlying dynamic process and then assess how well they fit, individually or in combination, to the available data (for a recent discussion about how mathematical modeling and expert judgment can be combined to achieve credible conclusions, see Weisberg 2010). To put it simply, then, the ideal move in (mostly) data-driven, historical, and correlational sciences like ours is from pattern to process and then again to pattern, in a recursive or iterative way (Amick et al. 1989).

Formal modeling and simulation effort about the impact of relevant variables (e.g., those that have been widely explored under the organization of technology model like, among others, mobility, land use patterns, overall levels of planning, and exchange paths; Beck et al. 2002; Brantingham 2006; Carr and Bradbury 2011; Close 2000; Charlin 2009; Féblot-Augustins 1993, 1997; Kelly 1988, 1992; Khun 1995, 2004; Nelson 1991; Surovell 2003) on the distributional patterns of artifacts and of their attributes (including raw materials) are yet very scarce and mostly focused on the short- or medium-term consequences of such variables (e.g., Brantingham 2003, 2006; Cole 2005; Grove 2010; Hodder 1978; Hodder and Orton 1976; Ingbar 1994). It cannot be overemphasized that more research on these topics is urgently needed in order to provide the basis for a probabilistic explanation of archaeological distributions, particularly in terms of the differential contribution of relevant factors and processes. However, it is important to take into account that most of the available models are framed into a synchronic and functional approach (Wandsnider 2003), in which processes are scoped at the short to medium term (ecological time). Any useful model has to incorporate a longer temporal perspective to fit the reality of the lithic component of the archaeological record, whose material and relational elements accumulate and changeas a consequence of postdepositional factors (Doelman 2008) - in evolutionary time.

\section{In Search of an Appropriate Form of Explanation}

Due to the insidious nature of equifinality, we think that a proper approach to the explanation of the empirically grounded inferences about the structure of lithic 
landscapes would be that proposed by Sober (1983), named the equilibrium explanation (EQ). This is an allegedly noncausal form of explanation (for a different interpretation, see Skow 2013; Strevens 2008) in which “....an outcome is explained by showing that a very large number of initial states of a system will evolve in such a way that the system ends up in the outcome state that we wish to explain, but in which no attempt is made to trace the actual sequence of events leading up to that outcome" (Woodward 2011). In fact, EQ is based on the assumption that to explain a given state of affairs, the identity of the "actual" cause does not really matter "as long as it is one of a set of possibilities of a certain kind" (Sober 1983, p. 140). To know what the actual cause of an event is - in the common view, the very objective of scientific researchwe have to be able to say which of a set of alternative answers is correct. If those alternatives are not easy to pry apart, knowing what the cause is may be difficult or even impossible to achieve (Sober 1983, p. 141). This is precisely the context in which EQ finds its relevance.

Equilibrium explanation is an account of explanation particularly useful for historical sciences like paleontology, geology, and archaeology to the extent that they deal with the effects - as they are seen from the present — of long past causes, particularly of causes whose necessity for the attributed effects is unknown. In contexts where equifinality is an issue, EQ appears as an adequate form of explanation that deserves further exploration in our field.

Summing up, the formulation of well-defined explanatory hypothesis about welldescribed patterns, the development of many simulative models designed to both, assessing the efficacy of different causal factors and processes and measuring the degree of overlapping of their effects, would constitute an adequate approach to cope with the problem of equifinality in the explanation of spatial patterning in the archaeological record.

\section{Descriptive/Interpretive Modeling of Lithic Landscapes: a Case Study}

The aim of this section is to introduce the application of the proposed methodology for the descriptive and interpretive modeling of lithic landscapes. We chose as an example a study case with which we are familiar, the Late Holocene lithic record of east-central Argentina, examining the spatial variation in relative frequency of three broadly defined classes of toolstone represented in lithic artifact assemblages (for a quite similar methodological approach, see Biró 1998; Biró and Regenye 1991). On the basis of the spatial models generated for each toolstone class, we address two main issues: (1) the relationship between, on one hand, the type and location of the sources and, on the other, the size and shape of the respective scatter areas; and (2) the reciprocal relationships between different raw material sources. It is expected that, beyond the specifics of the case, this example illustrates well both the problems and possibilities of the advocated approach.

The Study Area

The portion of the Argentine territory that we call east-central Argentina $\left(35.5^{\circ}\right.$ $-41.5^{\circ} \mathrm{S} ; 56.5^{\circ}-67.5^{\circ} \mathrm{W} ; \approx 480,000 \mathrm{~km}^{2}$ ) includes a significant section of the Pampas 
and the northeast of Patagonia (Fig. 5). The Pampas, a grassland/steppe biome inhabited by hunter-gatherers from the late Pleistocene to historical times, comprise a flat to slightly undulating surface landscape, which is alternatively underlain by deep layers of loess, loessoids, and sand. The Pampas are subdivided into two major environments: an eastern zone characterized by humid temperate prairies (Humid Pampas) and a western zone typified by dry steppes of moderate continental climate (Dry Pampas). This vast and continuous plain is interrupted by two major orographic systems, Tandilia and Ventania, smaller hilly ranges (e.g., Lihué-Calel, ChoiqueMahuida, Calencó), as well as by a number of isolated hills (e.g., Cerro Cortapié), and scattered rocky outcrops (e.g., Cuchillo Có, Lumb). Northeastern Patagonia is a semiarid region located south of the Colorado River. It comprises the lower valleys of the Colorado and Negro rivers, the intermediate plateau, and the coastal area. In this region, rocky outcrops are scarce and isolated (e.g., Cerro El Puntudo), being the most relevant geologic feature the Patagonian Shingle Formation (Tehuelche Beds or Rodados Patagónicos), composed of gravel deposits of extraregional provenance (Fidalgo and Riggi 1965, 1970; Martínez et al. 2009).

In east-central Argentina, there were two main kinds of raw materials used by prehistoric hunter-gatherers for tool-making: quartzites (orthoquartzites and methaquartzites) and cryptocrystalline quartz (e.g., chalcedonies and opaque siliceous rocks like jaspers, cherts, and silicified dolomite) (Andreis and Torres Ribeiro 2003; Dalla Salda et al. 2006; Harrington 1947). Other rocks like basalts, rhyolites, limestones, silicified tuffs, granites, or sandstones were also available (Harrington 1947; Linares et al. 1980), but they seem to have been of second order importance for subsistence activities. Despite the growing interest over the past three decades in the systematic and detailed study of lithic assemblages and in the detection of potential and factual sources of toolstone, very little of the lithic materials recovered in

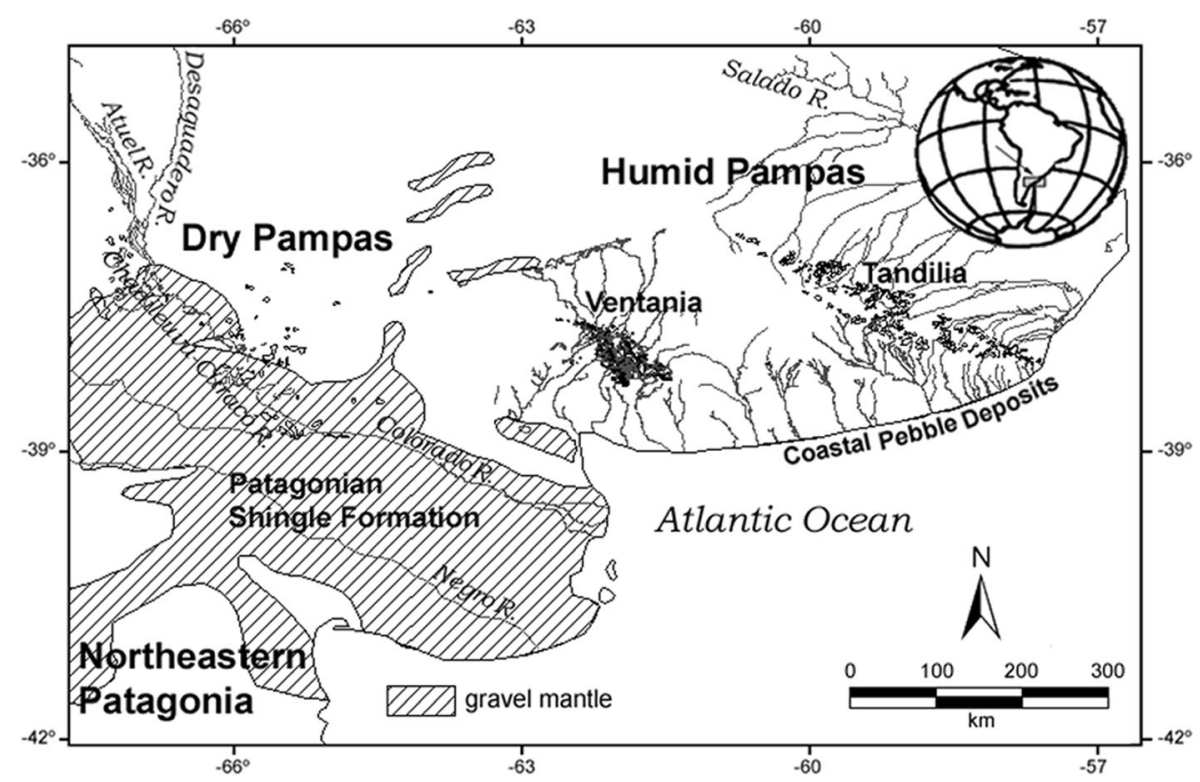

Fig. 5 Map of east-central Argentina showing the main orographic features and toolstone sources 
archaeological sites have been rigorously sourced using methods other than visual assessment of hand specimens. Among the few sourcing studies that used petrographic techniques (XRD and/or thin-section microscopy) carried out in our study area, we can mention those of Barros (2009), Barros and Messineo (2004), Bayón et al. (1999), Berón (2006), Catella (2014), Catella et al. (2010), Flegenheimer et al. (2003), Matarrese and Poiré (2009), Messineo et al. (2004), and Valverde (2002).

The sources of opaque siliceous rocks or ORS (e.g., cherts and jaspers) are very diffuse, in the sense of being extensive and difficult to delimit. These rocks appear, in relatively low proportions, intermixed with Andean igneous and metamorphic rocks (predominant), as well as other stones (e.g., chalcedonies, quartzites, quartz, silicified tuff, wood opal) within the extended gravel mantles of extraregional provenance that compose the Patagonian Shingle Formation (Martínez et al. 2009). Secondary sources of these toolstones are some derived formations, like the river gravel deposits associated with paleochannels of the Colorado River and the coastal pebble deposits of the Humid Pampas (the latter resulting from a complex process in which pebbles from the Patagonian Shingle Formation are transported to the sea by river streams, dispersed northward across the continental shelf by littoral currents, and then deposited on the Pampean beaches by storms and tides; Ameghino 1909; Frenguelli 1931) (Armentano 2004; Barros 2009; Berón 2006; Bonomo 2005; Bonomo and Prates 2014; Catella 2014; Fidalgo and Riggi 1965, 1970). Quartzites are abundant in Tandilia and Ventania, although there are smaller outcrops scattered over the plains of the Humid and Dry Pampas (Andreis and Torres Ribeiro 2003; Berón 2006; Charlin 2002; Flegenheimer and Bayón 2002; Kostadinoff 2007; Linares et al. 1980). From a geological standpoint, quartzites are present in at least 15 lithologic units in this region, most of them cropping out in Ventania and Tandilia (Dalla Salda et al. 2006; Harrington 1947; Linares et al. 1980). They present very different qualities for flintknapping and their sources, which have a different degree of availability, accessibility, and exploitability, are heterogeneously distributed across the landscape (Bayón et al. 1999; Catella 2014; Catella et al. 2010). However, the primary and secondary sources of high-quality raw materialsmostly orthoquartzites - are extremely scarce and localized (i.e., point sources) (Catella 2014; Catella et al. 2013; Colombo 2011, 2013).

The sources of chalcedonies, finally, are much less conspicuous than those of quartzites, but they are also highly localized, particularly the primary ones (Barros and Messineo 2004; Berón 2006; Cardillo and Scartascini 2007). The main diffuse sources of chalcedonies are the primary and secondary deposit of the Patagonian Shingle Formation (Berón 2006; Carrera Aizpitarte 2010).

Most of the secondary deposits of toolstones are of natural origin, but there are lines of evidence that, in some areas at least, the implementation by prehistoric huntergatherer of different provisioning strategies (Khun 1995, 2004), particularly at the level of places-i.e., through the formation of caches (Oliva and Perez 2008) or the transport and local accumulation of nodules or cores (Martínez 1999) - led to the lithification (sensu Webb 1993) of otherwise lithic-free landscapes (Martínez and Mackie 2003). Because only a very small fraction of the assemblages recovered at different archaeological sites have been rigorously sourced, it is relevant to check if the spatial variation in the proportion of each main toolstone class exhibits a coherent geographic pattern, in terms of frequency peaks and fall-off curves, particularly in relation with their factual and potential sources. 


\section{Materials and Methods}

In order to construct an exploratory model of the lithic landscape of east-central Argentina, we carried out an extensive survey of the relevant literature, searching for suitable quantitative data about the composition of lithic assemblages recovered from site components of Late Holocene age (ca. $3000-200{ }^{14} \mathrm{C}$ years BP). This time period, during which a number of significant processes seem to have been occurred (e.g., demographic increase, effective occupation of the entire territory, economic intensification, higher levels of interconnection across regional boundaries; Barrientos 1997; Bayón and Flegenheimer 2004; Berón 2004, 2007; González de Bonaveri et al. 1999; Martínez 1999, 2008-2009; Politis and Madrid 2001), is well represented archaeologically in the whole region. As a result, we collected a preliminary sample of around 150 georeferenced lithic assemblages. On the basis of the information provided by the corresponding reports, we calculated the relative frequency (i.e., percentages) of the toolstone classes represented in each assemblage. We choose percentages because they are useful for comparing information where the sample sizes or totals are very dissimilar and because they are a kind of data that is widely available in the literature. Any collection with less than 25 artifacts was excluded from the database since sample sizes below that minimum complicate the estimation of the relative frequencies.

To avoid the overcrowding of data from intensively surveyed areas in the landscape, we aggregated into composites the information from sites separated each other by a linear distance less than $1 \mathrm{~km}$ (i.e., an archaeological locality). It is deemed unproblematic, at the spatial scale in which the study was framed, the creation of composite assemblages by integrating data from very close sites whose boundaries, on the other hand, are generally not well specified in the literature. The aggregation of data has the advantage of avoiding the overcrowding of points, which is a problem in spatial analysis, while allowing retaining information from individual sites that, because of its small sample size, would be otherwise excluded from the analysis. The negative impact of this procedure on the overall picture can be considered negligible, taking into account the scale of our level of analysis, the rather small number of cases (20/119; $16.8 \%$ ), the particularities of the interpolation technique used to generate the spatial models, and the exploratory aim of this study. Data from the screened database $(n=119$; Table 1, Fig. 6) were, finally, entered into a spreadsheet for further analysis with the statistics software PAST 2.17 and the GIS package ArcGIS 9.3.

For the sake of simplicity, we chose to analyze the spatial distribution of artifacts made with raw materials belonging to just three groups of rocks, namely quartzites, chalcedonies, and OSR. These toolstones are those with the highest level of representation in the archaeological assemblages and those whose main sources are relatively known, albeit in a generic rather than a specific way. Although recent studies carried out in the study area have shown that these broad classes of rocks are composed by a variety of subtypes, like metaquartzites, orthoquartzites, and quartz sandstones in the case of quartzites (Bayón et al. 1999; Catella 2014; Catella et al. 2010, 2013), and different kinds of cherts, jaspers, and other silicified stones in the case of OSR (Armentano 2004, Martinez et al. 2009), in this paper, we decided to use broad categories for two reasons: (i) because the relevant information to establish a greater discrimination is not present in most of the reports used to generate the regional database and (ii) because the relative underdevelopment of intensive sourcing research in the area. 
Table 1 Archaeological sample from east-central Argentina utilized to model lithic landscapes

\begin{tabular}{|c|c|c|c|c|c|c|}
\hline No. & Site/locality & Sample Size & $\%$ OSR & $\%$ Qtzt & $\%$ Cha & References \\
\hline 1 & Agua del Fresco & 39 & 38.46 & 0.00 & 0.00 & Berón (2004) \\
\hline 2 & Angostura 1 & 998 & 45.29 & 0.10 & 7.62 & Prates (2008) \\
\hline 3 & Arenas Verdes & 95 & $3.20^{\mathrm{a}}$ & 66.40 & 9.50 & Bonomo (2005) \\
\hline 4 & Arroyo Saudade 1 & 109 & 0.00 & 100.00 & 0.00 & Catella et al. (2013) \\
\hline 5 & Arroyo Seco 2 & 143 & 2.80 & 60.84 & 4.90 & Leipus (2006) \\
\hline 6 & Badal & 194 & 3.60 & 0.00 & 84.53 & Austral (1971) \\
\hline 7 & Blanca Grande & 364 & 6.04 & 60.71 & 30.49 & Bórmida (1960) \\
\hline 8 & Cabeza de Buey & 165 & 2.42 & 64.24 & 33.33 & Bórmida (1960) \\
\hline 9 & Caldén Guazú M1SE & 426 & 52.00 & 2.64 & 14.39 & Armentano (2004) \\
\hline 10 & Calera Avellaneda & 5,258 & 1.00 & 25.90 & 69.68 & Barros and Messineo (2007) \\
\hline 11 & Campo Brochetto & 91 & 0.00 & 32.80 & 62.60 & Barrientos and Leipus (1997) \\
\hline 12 & Cantera Barker & $\mathrm{s} / \mathrm{d}$ & $0.00^{\mathrm{b}}$ & $98.00^{\mathrm{b}}$ & $2.00^{\mathrm{b}}$ & Flegenheimer et al. (1996) \\
\hline 13 & Cantera La Liebre & 1,153 & 0.00 & 7.00 & 0.00 & Flegenheimer (1991) \\
\hline 14 & Caracolero & 102 & 2.90 & 11.70 & 5.90 & Madrid et al. (2002) \\
\hline 15 & Cerro Aguirre & 663 & 0.00 & 0.00 & 100.00 & Lozano (1991) \\
\hline 16 & Cerro Casa de Piedra 1 & 278 & 37.65 & 0.00 & 0.00 & Gradín (1984) \\
\hline 17 & Cerro Cortado COMP & 29 & 65.52 & 0.00 & 0.00 & Berón (2004) \\
\hline 18 & Cerro La China COMP & 480 & 0.00 & 94.18 & 2.83 & $\begin{array}{l}\text { Mazzia and Flegenheimer } \\
\text { (2007) }\end{array}$ \\
\hline 19 & Cerro Núcleo Central-1 & 558 & 0.00 & 10.03 & 89.61 & Barros and Messineo (2004) \\
\hline 20 & Cerro Tres Lomas 1 & 8,372 & 0.00 & 3.58 & 4.12 & Messineo et al. (2009) \\
\hline 21 & Chenque 1-La Casona COMP & 1,376 & 57.85 & 1.89 & 0.00 & Berón (2004) \\
\hline 22 & Claromecó 1 & 423 & 7.32 & 2.00 & 1.60 & Bonomo et al. (2008) \\
\hline 23 & Confluencia 1 and 2 COMP & 250 & 44.80 & 0.80 & 0.00 & Berón (2004) \\
\hline 24 & Costa Bonita COMP & 1,115 & 32.64 & 5.56 & 0.26 & Loponte (1987) \\
\hline 25 & Cueva del Tigre & 156 & 2.60 & 58.30 & 22.50 & Madrid et al. (2002) \\
\hline 26 & Cueva Tixi & 1,304 & 0.31 & 97.08 & 0.15 & Mazzanti (1997) \\
\hline 27 & Dique Lara COMP & 404 & 28.71 & 0.00 & 17.33 & Berón (2004) \\
\hline 28 & Don Aldo 1 & 130 & 24.60 & 0.00 & 16.90 & Prates (2008) \\
\hline 29 & El Caldén & 2,136 & 19.19 & 2.80 & 26.96 & Armentano (2010) \\
\hline 30 & El Carancho & 72 & 0.00 & 0.00 & 0.00 & Berón (2004) \\
\hline 31 & El Castillo & 138 & 63.76 & 0.00 & 0.00 & Berón (2004) \\
\hline 32 & El Cruce & 35 & 51.42 & 0.00 & 0.00 & Berón (2004) \\
\hline 33 & El Encuentro & 137 & 32.84 & 0.00 & 0.00 & Berón (2004) \\
\hline 34 & El Guanaco 1 & 750 & 1.60 & 70.53 & 4.13 & Bayón et al. (2006) \\
\hline 35 & El Molino & 40 & 52.50 & 0.00 & 0.00 & Berón (2004) \\
\hline 36 & El Palomar 1 and 2 COMP & 292 & 18.49 & 65.41 & 0.34 & Austral (1965) \\
\hline 37 & El Puente & 919 & 0.00 & 33.62 & 53.32 & Kaufmann and Messineo (2010) \\
\hline 38 & El Puma 1,3, and 4 COMP & 4,564 & 20.95 & 1.60 & 15.95 & Martínez et al. (2012) \\
\hline 39 & El Remanso Grande & 152 & 64.47 & 0.66 & 0.00 & Berón (2004). Curtoni (1999) \\
\hline 40 & El Tigre HCSN & 219 & 45.12 & 0.47 & 44.65 & Armentano (2004) \\
\hline
\end{tabular}


Table 1 (continued)

\begin{tabular}{|c|c|c|c|c|c|c|}
\hline No. & Site/locality & Sample Size & $\%$ OSR & $\%$ Qtzt & $\%$ Cha & References \\
\hline 41 & Escuela Agropecuaria & 1,962 & 0.15 & 58.46 & 39.44 & Crivelli Montero et al. (1994) \\
\hline 42 & Faro Guaraní 1 & 122 & 1.60 & 0.80 & 0.80 & Bonomo (2005) \\
\hline 43 & Farola de Monte Hermoso & 207 & 0.00 & 90.82 & 0.48 & Bayón and Zavala (1994) \\
\hline 44 & Flor del Pago & 53 & 88.68 & 0.00 & 0.00 & Berón (2004) \\
\hline 45 & Fortín Necochea 1 & 3,098 & 0.00 & 68.84 & 29.24 & Crivelli Montero et al. (1994) \\
\hline 46 & Gascón 1 & 139 & 1.48 & 32.59 & 19.25 & Oliva et al. (2007) \\
\hline 47 & Jagüel & 9,138 & 6.00 & 68.00 & 15.00 & Saghessi and Petz (2007) \\
\hline 48 & La Colorada 1 to 6 COMP & 577 & 0.00 & 92.55 & 7.45 & Aldazabal and Cáceres (1999) \\
\hline 49 & La Estafeta 1 & 428 & 1.40 & 77.10 & 14.30 & Bonomo (2005) \\
\hline 50 & La Isla & 920 & 0.43 & 85.32 & 0.65 & Bayón et al. (2006) \\
\hline 51 & La Montaña & 652 & 3.53 & 40.00 & 6.75 & Catella (2014), Oliva (2014) \\
\hline 52 & La Primavera & 179 & 43.57 & 10.71 & 8.57 & Armentano (2004) \\
\hline 53 & La Raquel 2 & 1,678 & 4.00 & 49.47 & 37.41 & Eugenio et al. (2007) \\
\hline 54 & La Soberana & 30 & 2.56 & 56.41 & 2.56 & Bayón et al. (2006) \\
\hline 55 & La Sofía COMP & 55 & 1.82 & 81.82 & 1.82 & Catella (2014), Oliva (2014) \\
\hline 56 & $\begin{array}{l}\text { La Terracita-La Lomita } \\
\text { COMP }\end{array}$ & 75 & 61.33 & 0.00 & 0.00 & Berón (2004), Curtoni (1999) \\
\hline 57 & La Toma & 95 & 0.00 & 63.00 & 30.00 & Madrid and Politis (1991) \\
\hline 58 & Laguna Blanca Chica & 923 & 0.88 & 43.23 & 55.58 & $\begin{array}{l}\text { Barros and Messineo (2004), } \\
\text { Messineo and D'Augerot } \\
(2004)\end{array}$ \\
\hline 59 & $\begin{array}{l}\text { Laguna Chasicó } 1,5,6 \text {, and } \\
\text { HA COMP }\end{array}$ & 464 & 9.27 & 38.36 & 3.88 & Catella (2014) \\
\hline 60 & $\begin{array}{l}\text { Laguna Chasicó } 2 \text { and } 3 \\
\text { COMP }\end{array}$ & 429 & 35.43 & 25.41 & 7.69 & Catella (2014) \\
\hline 61 & Laguna Chasicó 4 & 30 & 3.33 & 26.67 & 23.33 & Catella (2014) \\
\hline 62 & Laguna Chasicó 7 & 187 & 14.43 & 56.68 & 6.41 & Catella (2014) \\
\hline 63 & Laguna Chasicó 8 & 221 & 2.26 & 81.44 & 2.71 & Catella (2014) \\
\hline 64 & $\begin{array}{l}\text { Laguna Chillhué 1, 2, and } 3 \\
\text { COMP }\end{array}$ & 279 & 54.48 & 26.52 & 0.00 & Berón et al. (2002-2004) \\
\hline 65 & Laguna Cubiló & 142 & 4.23 & 51.41 & 38.03 & Bórmida (n/d, 1960) \\
\hline 66 & Laguna de Chapalcó & 49 & 8.16 & 4.08 & 6.12 & Carrera Aizpitarte (2007) \\
\hline 67 & Laguna de Puán 1 & 112 & 0.00 & 80.00 & 8.00 & Oliva et al. (1991) \\
\hline 68 & Laguna de Rojo & 27 & 3.70 & 40.74 & 18.52 & Carrera Aizpitarte (2007) \\
\hline 69 & Laguna de Sotelo & 172 & 0.58 & 70.35 & 18.60 & $\begin{array}{l}\text { Eugenio and Aldazabal } \\
\quad(1987-1988)\end{array}$ \\
\hline 70 & Laguna del Trompa & 861 & 0.50 & 73.87 & 24.16 & Crivelli Montero et al. (1994) \\
\hline 71 & Laguna el Recado & 81 & 9.88 & 55.56 & 33.33 & Bórmida (1960) \\
\hline 72 & Laguna La Barrancosa 1 & 4,339 & 3.34 & 91.22 & 1.96 & Pal (2007) \\
\hline 73 & Laguna La Barrancosa 2 & 929 & 1.00 & 25.94 & 68.35 & Barros and Messineo (2004) \\
\hline 74 & Laguna La Dulce & 154 & 24.67 & 0.00 & 0.00 & Berón (2004) \\
\hline 75 & Laguna La Larga & 403 & 0.70 & 64.30 & 23.80 & Madrid et al. (2002) \\
\hline
\end{tabular}


Table 1 (continued)

\begin{tabular}{|c|c|c|c|c|c|c|}
\hline No. & Site/locality & Sample Size & $\%$ OSR & $\%$ Qtzt & $\%$ Cha & References \\
\hline 76 & Laguna La Leona & 33 & 63.63 & 0.00 & 0.00 & Berón (2004) \\
\hline 77 & Laguna Las Tunas Grande & 1,083 & 0.66 & 33.00 & 61.00 & Gavilán et al. (2004) \\
\hline 78 & Laguna Los Chilenos 2 & 463 & 2.59 & 76.46 & 6.91 & Catella (2014), Oliva (2014) \\
\hline 79 & Laguna Ovalla & 107 & 0.90 & 66.40 & 16.90 & Madrid et al. (2002) \\
\hline 80 & Laguna Pincén & 669 & 0.00 & 27.00 & 4.00 & Moirano (1999) \\
\hline 81 & Laguna Traru Lauquen & 47 & 0.00 & 0.00 & 0.00 & Berón (2004) \\
\hline 82 & Laguna Tres Reyes 1 & 77 & 3.35 & 71.18 & 13.48 & Madrid et al. (1991) \\
\hline 83 & Las Brusquillas 1 & 1,105 & 2.90 & 70.60 & 20.60 & Massigoge and $\mathrm{Pal}$ (2011) \\
\hline 84 & Las Cortaderas 1 & 253 & 0.00 & 85.80 & 13.40 & Massigoge (2007) \\
\hline 85 & $\begin{array}{l}\text { Localidad Parque Luro } \\
\text { COMP }\end{array}$ & 2,091 & 19.08 & 9.80 & 11.86 & Carrera Aizpitarte (2007) \\
\hline 86 & $\begin{array}{l}\text { Localidad Tapera Moreira } \\
\text { COMP }\end{array}$ & 669 & 51.87 & 1.20 & 0.00 & Berón (2004), Curtoni (1999) \\
\hline 87 & Loma de los Muertos & 207 & 35.00 & 1.45 & 10.00 & Prates et al. (2010) \\
\hline 88 & Loma Ruiz 1 & 268 & 20.40 & 18.90 & 16.60 & Martínez (2004) \\
\hline 89 & Los Sandovales & 31 & 90.32 & 0.00 & 0.00 & Berón (2004) \\
\hline 90 & Mar del Sur & 226 & 6.60 & 3.50 & 4.00 & Bonomo (2005) \\
\hline 91 & Médano Blanco & 94 & 0.00 & 97.87 & 0.00 & Bayón and Zavala (1994) \\
\hline 92 & Médano Santa Clara & 347 & 0.00 & 19.30 & 43.51 & Madrazo (1972) \\
\hline 93 & Médanos Colorados & 447 & 0.00 & 1.10 & 75.33 & Austral (1975) \\
\hline 94 & Médanos de Villa & 66 & 68.18 & 0.00 & 0.00 & Berón (2004) \\
\hline 95 & Médanos del 18 COMP & 544 & 36.21 & 0.18 & 0.00 & Berón (2004) \\
\hline 96 & Médanos del 24 & 162 & 41.98 & 0.00 & 0.00 & Berón (2004) \\
\hline 97 & Médanos del Fondo & 25 & 56.00 & 0.00 & 0.00 & Berón (2004) \\
\hline 98 & Memoria del Fresco & 746 & 8.17 & 0.00 & 0.00 & Berón (2004) \\
\hline 99 & Moromar & 295 & 9.80 & 2.00 & 0.70 & Bonomo (2005) \\
\hline 100 & Negro Muerto & 981 & 59.79 & 0.10 & 13.64 & Prates (2008) \\
\hline 101 & Nutria Mansa 1 & 1,603 & 1.70 & 82.10 & 5.00 & Bonomo (2005) \\
\hline 102 & Paso Mayor 1 and 2 COMP & 173 & 0.58 & 91.91 & 0.58 & $\begin{array}{l}\text { Austral (1967-1968), } \\
\text { Bayón et al. (2006) }\end{array}$ \\
\hline 103 & Ponciano Anquito & 154 & 66.88 & 3.25 & 0.00 & Berón (2004), Curtoni (1999) \\
\hline 104 & Puesto Córdoba & 30 & 30.00 & 3.33 & 0.00 & Berón (2004), Curtoni (1999) \\
\hline 105 & Puesto Patiño & 58 & 36.21 & 0.00 & 0.00 & Berón (2004) \\
\hline 106 & Quequén Salado 1 & 4,559 & 9.50 & 36.80 & 17.80 & Bonomo (2005) \\
\hline 107 & $\begin{array}{l}\text { Quequén Salado } 3 \text { and } 4 \\
\text { COMP }\end{array}$ & 67 & 2.98 & 80.59 & 11.94 & Madrid et al. (2002) \\
\hline 108 & Rincón del Álamo & 26 & 42.30 & 0.00 & 0.00 & Berón (2004) \\
\hline 109 & Salinas Chicas & 29 & 24.14 & 13.79 & 10.34 & Catella (2014) \\
\hline 110 & San Antonio & 560 & 55.18 & 1.43 & 27.86 & Martínez et al. (2010) \\
\hline 111 & San Blas COMP & 4,588 & 28.47 & 0.07 & 0.02 & $\begin{array}{l}\text { Eugenio and Aldazábal (2004), } \\
\text { Outes (1907) }\end{array}$ \\
\hline 112 & San Luis & 217 & 0.90 & 80.60 & 13.40 & Massigoge (2007) \\
\hline
\end{tabular}


Table 1 (continued)

\begin{tabular}{lllllll}
\hline No. & Site/locality & Sample Size & \% OSR & \% Qtzt & \% Cha & References \\
\hline 113 & San Martín 1 & 498 & 3.22 & 79.72 & 4.02 & Catella et al. (2010) \\
114 & Tapera Vieja de Juárez & 225 & 49.33 & 0.00 & 0.00 & Berón (2004) \\
115 & Vallejo & 26 & $0.00^{\mathrm{c}}$ & $2.70^{\mathrm{c}}$ & $45.94^{\mathrm{c}}$ & Austral (1971) \\
116 & Villa Iris & 384 & 12.50 & 22.91 & 13.54 & Oliva et al. (2006) \\
117 & Voladero Tulli & 233 & 41.70 & 4.04 & 13.00 & Armentano (2004) \\
118 & Ybarra & 186 & 0.00 & 75.00 & 10.00 & Moirano (1999) \\
119 & Zanjón Seco 2 & 1,007 & 0.16 & 96.60 & 1.86 & Politis et al. (2004) \\
\hline
\end{tabular}

OSR opaque siliceous rocks, Qtzt quartzites, Cha chalcedonies

${ }^{a}$ In the absence of a specific value given in the original report, \% OSR was calculated considering that these toolstones represent approximately $8 \%$ of the raw materials of "coastal origin," a category that includes OSR, andesites, rhyolites, basalts, and other rocks (Bonomo 2003, pp. 131-132)

${ }^{\mathrm{b}}$ Percentages estimated on the basis of the descriptive account of site findings

${ }^{\mathrm{c}}$ Percentages calculated considering only the tool assemblage

Our records fall into the category "sparsely sampled data" (Dixon 2002), since only a subset of all possible event locations has been observed and recorded by the authors of the reports (i.e., preferential sampling). The first step in our analysis was to assess the spatial distribution of sample locations - considered as marked point process data (Stoyan and Stoyan 1994) - by means of a nearest neighbor analysis. The results of the test (convex hull area, Donnelly edge effect correction; nearest neighbor ratio

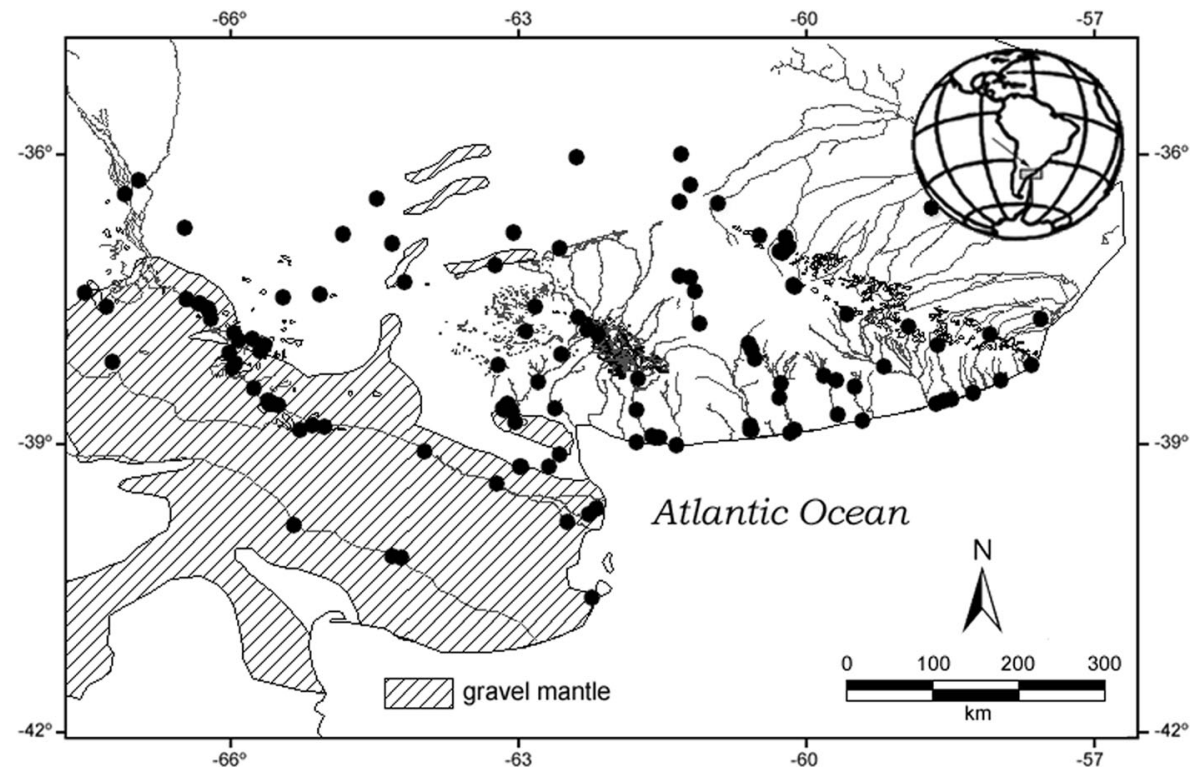

Fig. 6 Spatial distribution of the sampling units (archaeological sites and localities) used as data source for the construction of spatial models of the lithic landscapes from east-central Argentina 
$R=0.7917 ; z$ score $=-4.0425 ; p$ value $<0.001)$ indicate that the point pattern is clustered, making necessary the implementation of a declustering procedure to adjust for preferential sampling (cell method; Journel 1983). Following a common practice to choose the cell size for declustering, we first proceeded - after performing a normal score transformation of original values - to compute the global mean percentage for a range of cell sizes and then to select the cell size that returned the lowest global mean $(\mu)$ (Contaminated Sites Statistical Applications Guidance 2001, p. 2). The second step was to test for trends and anisotropies in data distributions. The third step was to examine the spatial dependence of data using different semivariogram models. At this step, data were analyzed with and without correction for trends or anisotropy. The comparison between the performance of different geostatistical models, considering both the variography and the cross-validation statistics, indicates that the best overall results were obtained with the use of the K-Bessel or Matern model (detrended data, corrected for anisotropy). It is a model that tends to produce surfaces that are smoother locally (i.e., on a very fine scale) than those generated by other models (Pardo-Iguzquiza and Chica-Olmo 2008). The fourth step was the generation of prediction maps and prediction standard error maps for each of the three toolstone classes by means of simple kriging (different semivariogram models), using for the interpolation between 7 and 10 neighbors within each quadrant of the map. Both map classes were exported to a raster format for further examination and processing.

It is important to note here that spatial models based on relative frequency data contain information not only about the rock class represented in each map but also about the relationships between it and all the other rock classes - and their respective sources - defined in a region (Ingbar 1994). In fact, at each point in the space, any one toolstone can be present at a relative frequency $(f)$ with a probability $(p)$ that is not a simple function of distance from the source but a function of distance from source, plus a number of intrinsic and extrinsic properties of the rock itself (e.g., mineral composition, internal structure, degree of metamorphism, hardness, fracture) and those of its source (e.g., size, visibility, exploitability) in relation with those of the other available rocks and sources. Therefore, the shape of the fall-off curve obtained from relative frequency data can significantly differ from that derived from other measures like absolute frequency, density, or weight (see examples in Bevan 2012). This makes relative frequency data and derived models particularly indicative about the kind of reciprocal relationship between different regionally available raw materials and sources (Biró and Regenye 1991; Fulford and Hodder 1974; Hodder and Orton 1976; Soja 1971).

Summarizing, in this exploratory study, the unit of analysis is the lithic landscape, which is modeled separately for each toolstone class. The level of analysis is the macroregion (the Pampas and northeastern Patagonia), and the unit of observation is the site or locality.

\section{Results and Discussion}

Figures 7, 8, and 9 represent the 2D models of the lithic landscapes corresponding to each of the three toolstone classes considered (simple kriging, K-Bessel semivariogram; for a summary of the error statistics associated with these models, 

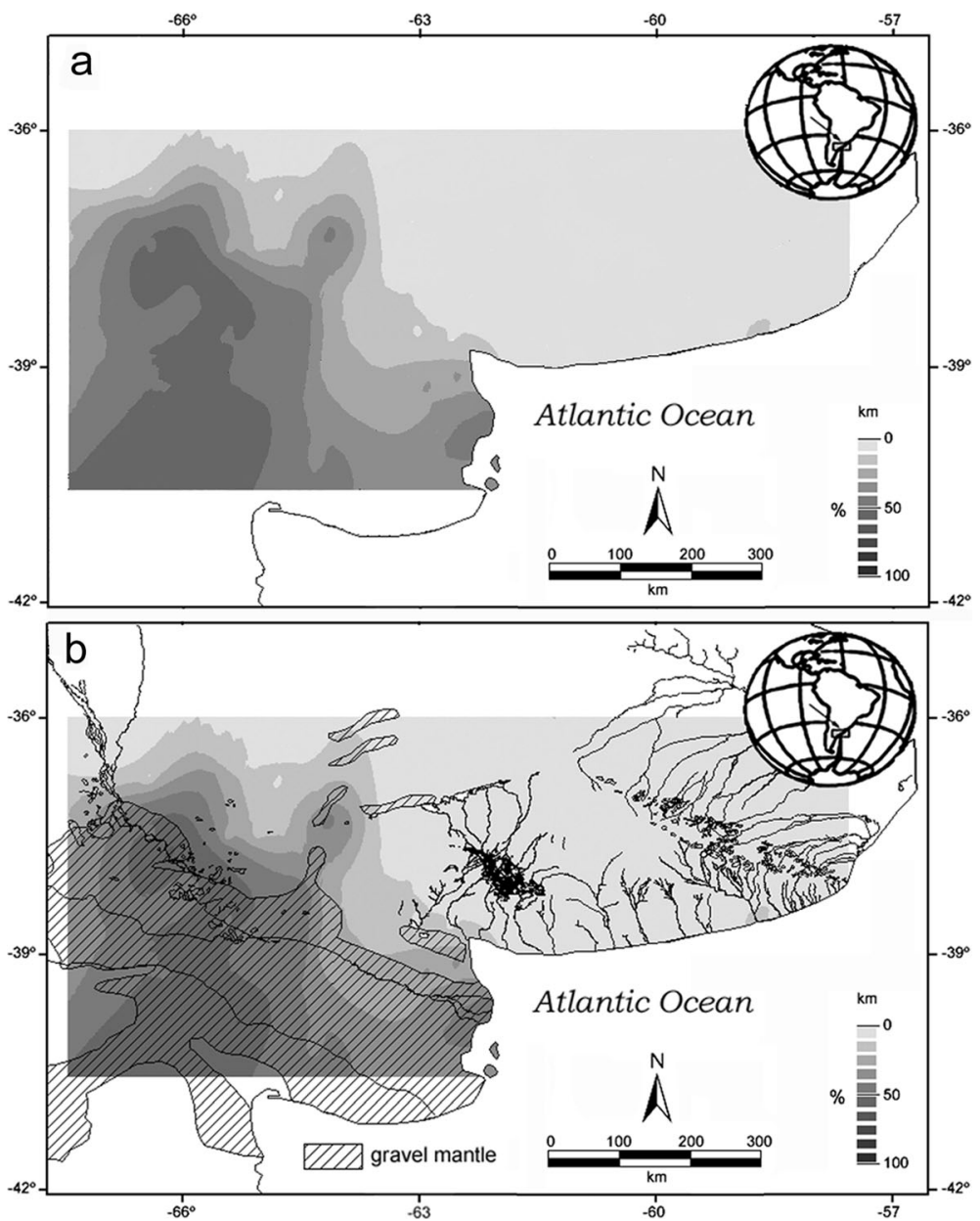

Fig. 7 Continuous spatial model (raster map) of the lithic landscape of opaque siliceous rocks (OSR) from east-central Argentina (relative frequency data); a without physiographic information; b with sources, water courses, and water bodies

see Table 2). As it is shown in Fig. 7, OSR have a spatial distribution of percentage values that is highly congruent with the distribution of the Patagonian Shingle Formation and of the pebble deposits found along the coast of the Humid Pampas. The highest percentage values of these rocks (50-70\%) are found around the middle valleys of the Negro and Colorado rivers and along most of the Chadileuvú-Curacó river valley, which are zones that are either well inside the major regional mantle of the Patagonian Shingle Formation or slightly displaced with respect to its northern edge. Lesser peaks (30-40\%) occur in the lower valley and delta of the Colorado River and in relation with minor and isolated deposits of Rodados Patagónicos, which are usually composed of pebbles of smaller size with respect to those from the major, western sources (Witte 1916). Quartzites are mainly concentrated (50+\%) around and between the hills of Tandilia and Ventania (Fig. 8), where the main primary sources of quartzites crop out. However, in and around both hilly ranges, the highest peaks of these raw 

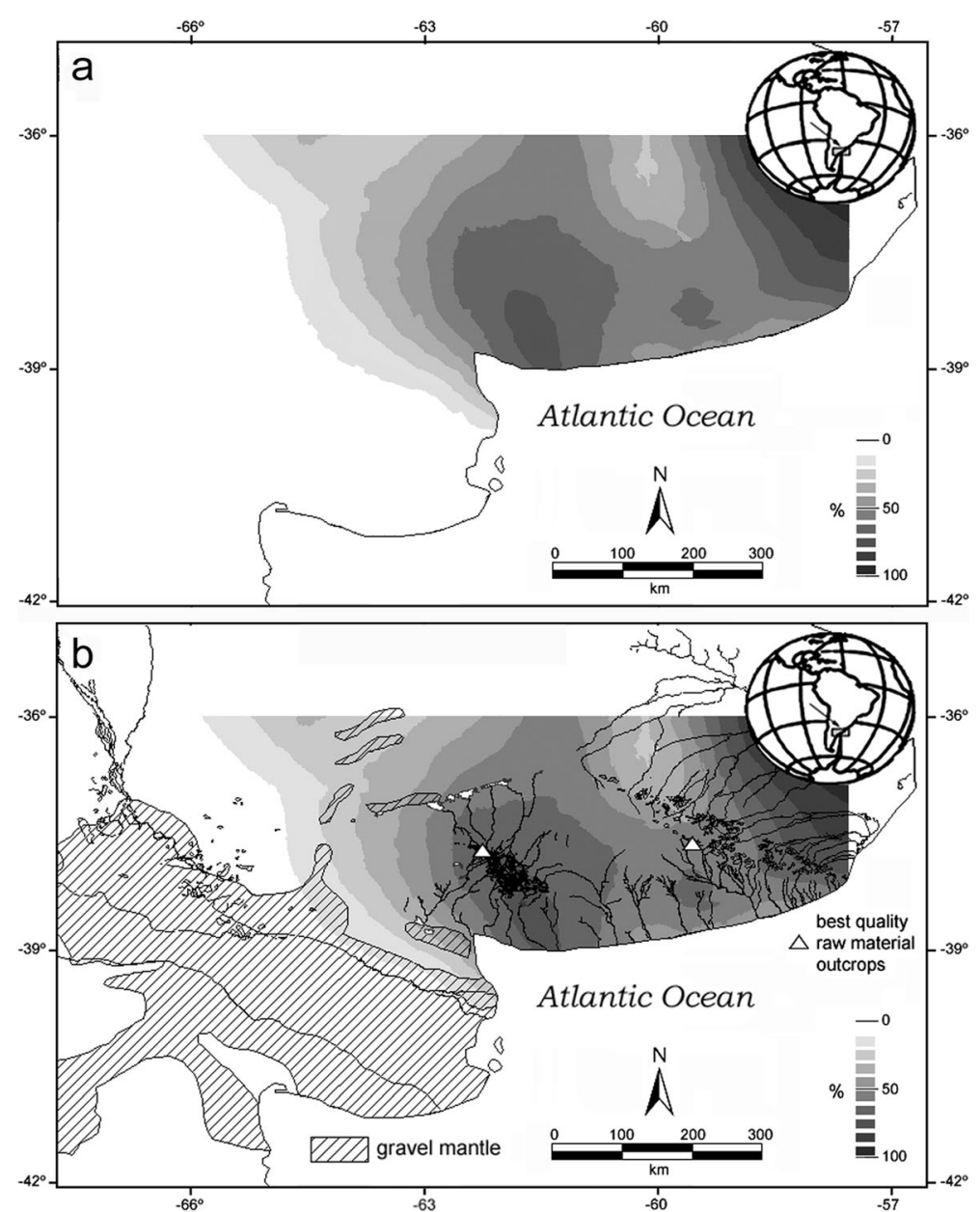

Fig. 8 Continuous spatial model (raster map) of the lithic landscape of quartzites from east-central Argentina (relative frequency data); a without physiographic information; b with sources, water courses, and water bodies

materials (70-80\%) do not appear to be preferentially associated with any particular type of source (i.e., primary or secondary sources). Chalcedonies (Fig. 9), in turn, are the most ubiquitous toolstones at the regional level, with at least four peaks of relative frequency distributed in different sectors of space. However, in just one case, coincidence between a frequency peak and a known source was found, which suggests that chalcedony sources - some of them likely not discovered so far-are present in diverse points of the landscape. This is particularly evident in the northern side of the study area, where there are more percentage peaks $(50+\%)$ than identified sources. By contrast, in the south and the western sector of the area, there are at least two documented sources that seem to have been exploited at a very local level. The primary sources of OSR are diffuse and those of quartzites and chalcedonies are both point and diffuse, whereas the secondary sources of all these toolstones are predominantly diffuse. These facts introduce variability in the form that scatter areas around each 

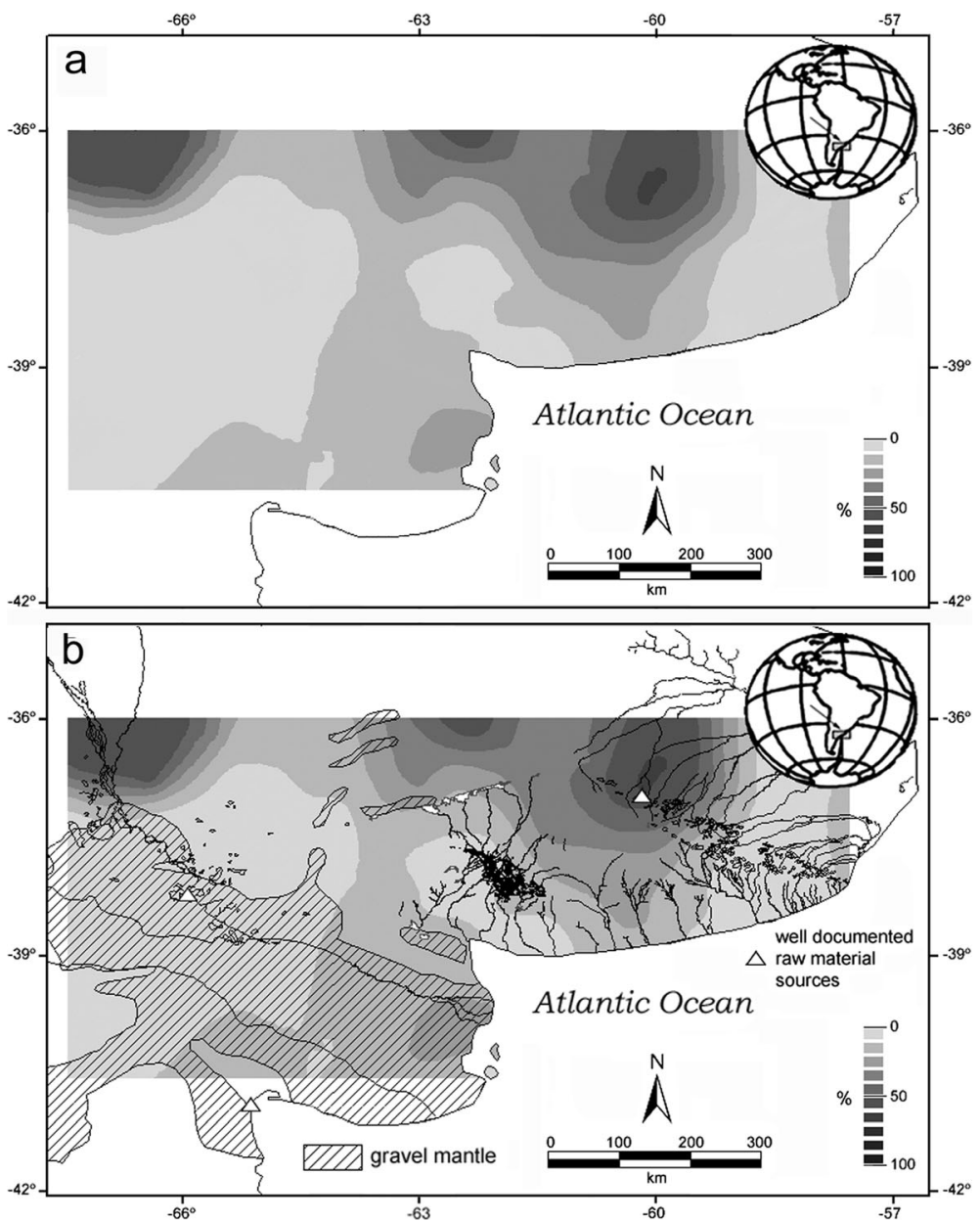

Fig. 9 Continuous spatial model (raster map) of the lithic landscape of chalcedonies from east-central Argentina (relative frequency data); a without physiographic information; b with sources, water courses, and water bodies

source adopt. In the case of OSR, an irregularly shaped and extended scatter area tends to map onto the entire distribution of the major and minor mantles of the Patagonian Shingle Formation (Fig. 7). The highest percentage peak (60-70\%) is not constrained to a relatively small area, but it has a very wide spatial expression. This contrasts with

Table 2 Standard error statistics associated to each continuous surface model (simple kriging, K-Bessel semivariogram)

\begin{tabular}{llllll}
\hline Toolstone class & Min & Max & Mean & Std. dev. & Median \\
\hline OSR & 11.15 & 13.81 & 13.56 & 0.17 & 13.59 \\
Quartzites & 17.97 & 19.13 & 18.51 & 0.23 & 18.51 \\
Chalcedonies & 8.70 & 17.29 & 17.28 & 0.28 & 17.29 \\
\hline
\end{tabular}


the distribution of the scatter area around the best described group of point sources of chalcedony, situated in the northwestern extreme of Tandilia (Sierras Bayas) (Barros 2009; Barros and Messineo 2004; Lozano 1991) (Fig. 9). In this case, such area has a somewhat subconical shape around the cluster of sources, at least between the range of 40 and $70 \%$, with a smaller and well-delineated maximum percentage peak area (60$70 \%$ ). Quartzites, in turn, have a more varied pattern of distribution of the scatter areas around the putative sources. In the center of the area, the highest frequency peak (70$80 \%$ ) occurs around the hills of Ventania and along the river basin of Sauce Grande-de las Mostazas, an area rich in both primary and secondary raw material sources of varied quality (Bayón and Zavala 1994; Catella et al. 2010). In the northeast, an even higher peak (90-100 \%) is found well inside the Salado River depression which, in contrast with the first, is an area entirely devoid of known sources of these and other raw materials. In this case, however, the increasing SW-NE gradient in percentage values and the height of the peak are strongly influenced by the extremely low density of data points (Fig. 6), the border effect associated with the lack of samples located outside the study area, and the documented lack of raw material sources in the plains northeast from Tandilia. In this hilly range, the best known sources of high-quality quartzites (outcrops and secondary deposits of the Sierras Bayas Group, situated in the area of Barker-La Numancia; Colombo 2011, 2013) are included within an area of no particularly high percentage values (50-60\%) (Fig. 8), probably due to the competition with other good quality lithic raw materials (chalcedonies and silicified dolomites) whose main sources are within a maximum radius of about $100 \mathrm{~km}$ from these places (Barros 2009; Barros and Messineo 2004; Flegenheimer 1991; Fig. 9).

At this stage of the research, it is clear that the spatial models generated for each toolstone class have different heuristic value. In the case of OSR-whose sources are well known in terms of its location and extension but little known in terms of its internal variability in relation with key aspects such as visibility, accessibility, quality, and exploitability - the spatial models presented here can help to identify likely areas of preferential procurement (Fig. 7). This information can be used to design survey and sampling strategies aimed at improving the characterization of these diffuse sources. Regarding quartzites, while the knowledge about location and differential quality of the sources is acceptable, the relative contribution of each source to particular artifact assemblages is less known in the absence of a large-scale, technology-aided sourcing effort. The subconcentric distribution of the percentage intervals around Ventania (Fig. 8) allows establishing with any precision the likely area of influence of quartzites from primary and secondary sources distributed in and around these hills. This is important since it allows formulating hypotheses, on the basis of the geographical position of the recovered artifacts, about the likely origin of the quartzites represented, which can be further evaluated by applying different sourcing techniques. As for chalcedonies, finally, our spatial model (Fig. 9) is informative about the likely existence of not yet found sources distributed across the regional space. In this case, such information can be useful to guide and optimize both survey and sourcing efforts.

The last issue we want to discuss here refers to the reciprocal relationships between the three toolstone classes considered in this exploratory study. Figure 10 shows the modeled spatial continuous distribution of artifact assemblages in which one, two, or three of the measured rock classes are represented with percentage values equal or higher than $10 \%$ (classification of data and superimposition of the resulting layers with 


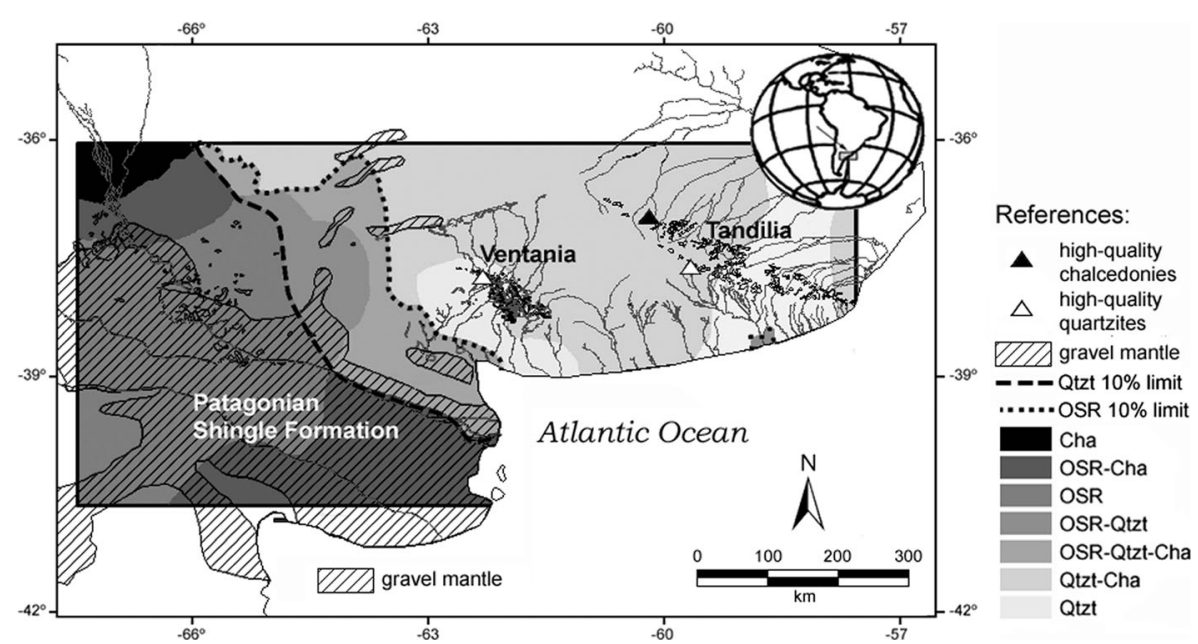

Fig. 10 Modeled spatial continuous distribution of artifact assemblages in which the three rock classes are represented with percentage values equal or higher than $10 \%$ (classification of data, superimposition and merging of layers with different degree of transparency)

different degree of transparency). Most of the Humid Pampas have a rather simple composition to the degree that most of the modeled surfaces correspond to areas dominated by either one or two toolstones (quartzites and quartzites-chalcedonies, respectively). In the Dry Pampas and northeastern Patagonia, the situation is more complex since in both regions there are areas dominated by one (OSR, chalcedonies), two (OSR-chalcedonies, OSR-quartzites), or three (OSR-chalcedonies-quartzites) rock classes. It is of particular interest the strip of land situated between the limits of $10 \%$ OSR and $10 \%$ quartzite, which has a uniform width of about $100 \mathrm{~km}$ and runs roughly parallel to the boundary between Humid Pampas and northeastern Patagonia in the south and Humid Pampas and Dry Pampas in the west. Within this area that encompasses the northern edge of the main outcrop of the Patagonian Shingle Formation as well as many other lesser gravel mantles of the same geological unit, the modeled surfaces combine principally two toolstones, OSR and quartzites. This zone allows for the examination of the reciprocal relationships between two groups of raw materials, one abundant in northern Patagonia and Dry Pampas - OSR - and other emblematic of the Humid Pampas - quartzites. In this regard, it is instructive to consider the shape of the respective fall-off curves as shown in Fig. 11. In this figure, we represented the curves of OSR and quartzites corresponding to two virtual transects drawn across the modeled surfaces with the aid of the ArcGIS 3D Analyst module. In general, the fall-off curves of both toolstones match the expected model of monotonic decline with increasing distance from the likely sources. In effect, in both cases, each peak in the respective distance decay curves coincides with the localization of either a major or minor putative source. Both curves tend to cross at points that are nearly equidistant from the major sources of OSR and quartzites (considering, in the latter case, the outcrops in the hills of Ventania and the pebble banks distributed along the streams that have their headwaters in these hills; Catella 2014). However, quartzites reach percentage values on or nearby their sources notoriously higher than those of OSR, thus implying that the effects of competition with alternative knappable materials at the 

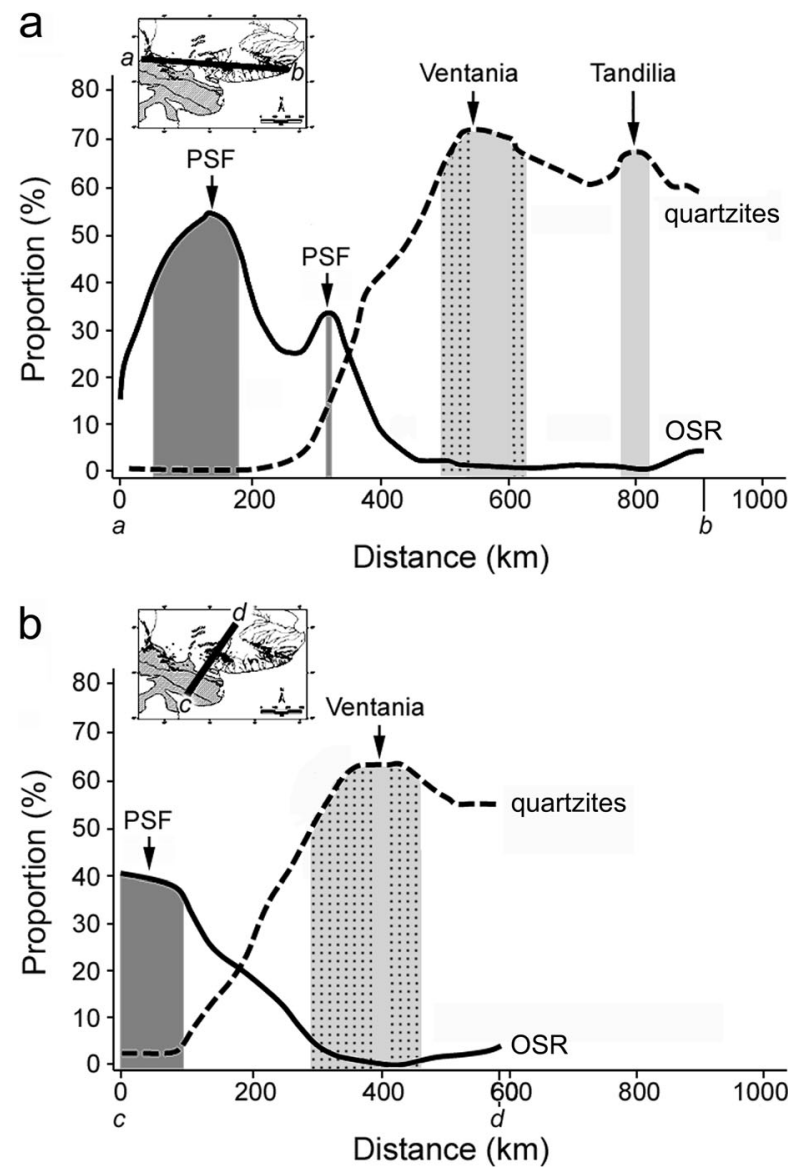

Fig. 11 Fall-off curves $(\mathbf{a}, \mathbf{b})$ of OSR and quartzites (relative frequency data) corresponding to two virtual transects ( $a-b$ in $\mathbf{a}$ and $c-d$ in $\mathbf{b})$ drawn across the modeled lithic landscapes The vertical stripes represent the position and extension of the potential sources of each toolstone class (OSR: dark gray; quartzites, primary sources: light gray; quartzites, secondary sources: light gray with dots)

sources are higher for OSR than for quartzites. In fact, as it was already mentioned, the main sources of OSR are the gravel deposits of the Patagonian Shingle Formation, composed of a relatively high variety of potential toolstones. In contrast, in Ventaniawhere the outcrops and most of the secondary deposits of quartzites are placed - there are fewer alternative raw material sources, being those of rhyolites and silicified limestones the most prominent among them (Catella 2014; Moirano 1999; Oliva and Moirano 1997), although the spatial distribution of artifact made on these stones is rather restricted (Barros 2009; Catella 2014; Moirano 1999; Oliva and Moirano 1997), thus suggesting that they have played a secondary role in the subsistence of Pampean populations through time. The construction of specific gravity models (Wilson 2007b) is an urgently needed task in order to test for this and other hypotheses about competitive interactions between different raw materials and sources.

Summarizing, we can say that the case study presented in this paper reveals the potential of the proposed approach for the archaeological study of lithic landscapes. 
Even in situations where the quality of the information about the total range of variability in both raw material sources and artifact assemblages is less than perfect and the particularities of the links between the two are yet not well known, the production of spatial continuous models can make a valuable contribution to the enhancement of our knowledge about distributional aspects of the regional lithic record. However, it is clear that in order to discuss spatial patterning in terms of the long-term effects of behavior and organization, a continuous feedback between spatial modeling and the acquisition of increasingly detailed information about lithic sources (e.g., distribution, visibility, accessibility, exploitability) and archaeological assemblages (e.g., distribution, composition, technology) is needed.

\section{Concluding Remarks}

The aim of this paper has been to introduce the concept of lithic landscape (which is, strictly speaking, a redefinition of a term already present in the literature; Gould and Saggers 1985, p. 124) and discuss what we consider the proper methodology for its modeling and study. The application of such a concept and methodology to the analysis of a specific case study helped to identify the strengths and weaknesses of the advocated approach.

Among the strengths, we can mention the ability of continuous spatial models to integrate, in a coherent picture, information that is widely scattered and inarticulate. In particular, the use of geostatistical tools for characterizing the spatial variation in quantitative data collected at georeferenced point locations allows for the creation of interpolated continuous surfaces together with estimated uncertainty in those surfaces. Through this procedure, it is possible to overcome, to some extent, the limitations imposed by the distribution of the spatial data (e.g., clustering, anisotropies). Within a GIS framework, the generated surface maps can be compared with each other and with different spatial datasets containing environmental and/or paleoenvironmental information about topography, hydrology, soils, or other relevant variables. This enables to investigate the reciprocal relationships between two or more raw materials and sources (a mostly neglected issue), as well as to assess the influence of landscape features on the form (i.e., size, shape) of the structural units identified in the modeled lithic landscapes. Another advantage of the continuous surface model applied to the study of the distribution of different toolstones is its ability to detect, on the basis of spatial differences in the value of the response variable, zones where the location of not yet discovered sources is more likely. This is important information that can guide the search for such sources.

The principal weakness of the proposed approach is the lack of control of field sampling procedures at the spatial scales in which it is usually meaningful to talk about lithic landscapes (i.e., meso- to macroscale). To the extent that it is extremely difficult for a single research project to develop fieldwork in such a wide scale, it is likely that quantitative and distributional data about several aspects of the lithic record will come from a heterogeneous combination of survey strategies deployed at different times by different research teams. This major drawback undoubtedly affects the quality of data available to model lithic landscapes. However, the continuous surface maps of the kind presented here, despite being based on imperfect (albeit perfectible) information, have 
the potential to guide future survey and sampling efforts in a more problem-oriented way.

As a final thought, we would like to emphasize that the importance of a proper description and analysis of the spatial structure of lithic landscapes resides in the fact that it is the needed baseline from which to formulate and assess different explanatory models (a long-term effort and something that we are just beginning to work on) about their underlying generative mechanisms, explicitly addressing the problem of equifinality and acknowledging — and taking advantage of - the palimpsest nature of the lithic record. It is precisely the development of an integrated approach based on the iterative interplay between empirical data, spatial modeling, and theory building via simulative experimentation within a coherent explanatory framework the true research challenge for the next years.

Acknowledgments We are grateful to Juan Bautista Belardi and three anonymous reviewers for their comments on the manuscript, which have been extremely constructive and helpful. This research was funded by grants from the Universidad Nacional de La Plata (UNLP-N629 and UNLP-N740) and Facultad de Humanidades y Artes, Universidad Nacional de Rosario (HUM-363), República Argentina.

\section{References}

Aldazabal, V., \& Cáceres, L. (1999). Primeras observaciones en el sitio arqueológico La Colorada, pdo. de Rauch. In C. Diez Marín (Ed.), Actas del XII Congreso Nacional de Arqueología Argentina 3 (pp. 95102). La Plata: Editorial de la Universidad Nacional de La Plata.

Aldenderfer, M. S. (1998). Montane foragers: Asana and the South Central Andean Archaic. Iowa City: University of Iowa Press.

Ameghino, F. (1909). Le Diprothomo platensis: Un précurseur de homme du Pliocéne infèrieur de Buenos Aires. Anales del Museo Nacional de Buenos Aires, 19(12), 107-209.

Amick, D. S. (1996). Regional patterns of Folsom mobility and land use in the American Southwest. World Archaeology, 27, 411-426.

Amick, D. S., Mauldin, R. P. \& Binford, L. R. (1989). The potential of experiments in lithic technology. In D. Amick \& R. Mauldin (Eds.), Experiments in lithic technology (pp. 1-14). BAR International Series 528. Oxford: Oxbow.

Andrefsky, W., Jr. (2009). The analysis of stone tool procurement, production, and maintenance. Journal of Archaeological Research, 17, 65-103.

Andreis, R. R., \& Torres Ribeiro, M. (2003). Estratigrafía, facies y evolución depositacional de la Formación Sauce Grande (Carbonífero Superior), Cuenca Sauce Grande, Sierras Australes, Buenos Aires, Argentina. Revista de la Asociación Geológica Argentina, 58, 137-165.

Andrews, L., Higgins, A. Waring Andrews, M. and Lalor, J. G. (2012) Classic grounded theory to analyse secondary data: reality and reflections. Grounded Theory Review, An International Journal, 11(1), http:// groundedtheoryreview.com/2012/06/01/classic-grounded-theory-to-analyse-secondary-data-reality-andreflections/. Accessed 21 Feb 2014.

Armentano, G. (2004). Organización de la tecnología lítica en el valle inferior del río Colorado (pdos. de Patagones y Villarino, pcia de Buenos Aires). Unpublished graduate dissertation. Olavarría: Facultad de Ciencias Sociales, Universidad Nacional del Centro de la Provincia de Buenos Aires.

Armentano, G. (2010). Análisis de la tecnología lítica del sitio El Caldén, Partido de Villarino, provincia de Buenos Aires. In M. Berón, L. Luna, M. Bonomo, C. Montalvo, C. Aranda, \& M. Carrera Aizpitarte (Eds.), Mamül Mapu: Pasado y presente desde la arqueología pampeana 2 (pp. 191-200). Ayacucho: Editorial Libros del Espinillo.

Aston, M., \& Rowley, T. (1974). Landscape archaeology: an introduction to fieldwork techniques on postRoman landscapes. Newton Abbot: David \& Charles.

Ataman, K., Carambelas, K., \& Elston, R. G. (1992). The economics of toolstone extraction and processing. In R. G. Elston \& C. Raven (Eds.), Archaeological Investigations at Tosawihi, a Great Basin Quarry, part 3: a perspective from locality 36 (pp. 233-250). Silver City: Intermountain Research. 
Atici, L., Kansa, S. W., Lev-Tov, J., \& Kansa, E. C. (2013). Other people's data: a demonstration of the imperative of publishing primary data. Journal of Archaeological Method and Theory, 20, 663-681.

Austral, A. (1965). Investigaciones prehistóricas en el curso inferior del río Sauce Grande. Trabajos de Prehistoria, 19, 7-123.

Austral, A. (1967). Los hallazgos arqueológicos de Paso Mayor II. Pdo. de Coronel Pringles. Pcia. de Buenos Aires. Cuadernos del Sur, 8-9, 1-32.

Austral, A. (1971). El yacimiento arqueológico Vallejo en el noroeste de la provincia de La Pampa. Contribución a la sistematización de la prehistoria y arqueología de la región Pampeana. Relaciones de la Sociedad Argentina de Antropología (N. S.), 2, 49-70.

Austral, A. (1975). El yacimiento arqueológico de Médanos Colorados. Relaciones de la Sociedad Argentina de Antropología (N. S.), 9, 119-133.

Azpurua, M., \& Dos Ramos, K. (2010). A comparison of spatial interpolation methods for estimation of average electromagnetic field magnitude. Progress in Electromagnetics Research, M, 14, 135-145.

Bailey, G. N. (1981). Concepts, time-scales and explanations in economic prehistory. In A. Sheridan \& G. Bailey (Eds.), Economic archaeology (pp. 97-117). BAR International Series 96. Oxford: Oxbow.

Bailey, G. N. (2007). Time perspectives, palimpsests, and the archaeology of time. Journal of Anthropological Archaeology, 26, 198-223.

Bakken, K. E. (2011). Lithic raw material use patterns in Minnesota. Unpublished doctoral dissertation. Minneapolis: Faculty of the Graduate School of the University of Minnesota.

Bamforth, D. B. (1986). Technological efficiency and tool curation. American Antiquity, 51, 38-50.

Bamforth, D. B. (2006). The windy ridge quartzite quarry: hunter-gatherer mining and hunter-gatherer land use on the North American Continental Divide. World Archaeology, 38, 511-527.

Bamforth, D. B., \& Woodman, P. (2004). Tool hoards and Neolithic use of the landscape in northeastern Ireland. Oxford Journal of Archaeology, 23, 21-44.

Banning, E. B. (2002). Archaeological survey. New York: Kluwer Acedemic/Plenum.

Barrientos, G. (1997). Nutrición y dieta de las poblaciones aborígenes prehispánicas del sudeste de la Región Pampeana. Unpublished doctoral dissertation. La Plata: Facultad de Ciencias Naturales y Museo, Universidad Nacional de La Plata.

Barrientos, G. \& Leipus, M. (1997). Recientes investigaciones arqueológicas en el sitio Campo Brochetto (Partido de Tres Arroyos, Pcia de Buenos Aires). In M. Berón \& G. Politis (Comps.), Arqueología pampeana en la década de los '90 (pp. 35-46). San Rafael: Museo de Historia Natural de San Rafael.

Barros, M. P. (2009). Analyses des strategies d'acquisition et de production lithique dans la Region Pampeana, province de Buenos Aires, Argentine. Unpublished doctoral dissertation. Paris: Universite Paris Ouest Nanterre La Defense U.F.R de Sciences Sociales et Administratives.

Barros, M. P., \& Messineo, P. G. (2004). Identificación y aprovisionamiento de chert o ftanita en la cuenca superior del Arroyo Tapalqué. Estudios Atacameños, 28, 87-103.

Barros, M. P., \& Messineo, P. G. (2007). Producción lítica en el sitio Calera (Sierras Bayas, Región Pampeana). In C. Bayón, A. Pupio, M. I. González, N. Flegenheimer, \& M. Frère (Eds.), Arqueología en las Pampas 2 (pp. 721-744). Buenos Aires: Sociedad Argentina de Antropología.

Barton, C. M., Clark, G. A., Yesner, D. R., \& Pearson, G. A. (Eds.). (2004). The settlement of the American continents: a multidisciplinary approach to human biogeography. Tucson: University of Arizona Press.

Barton, C., Joan Bernabeu, M., Aura, J. E., \& Garcia, O. (1999). Land-use dynamics and socioeconomic change: an example from the Polop Alto Valley. American Antiquity, 64, 609-634.

Barton, C., Joan Bernabeu, M., Aura, J. E., Garcia, O., \& La Roca, N. (2002). Dynamic landscapes, artifact taphonomy, and land use modeling in the western Mediterranean. Geoarchaeology, 17, 155-190.

Bayón, C., \& Flegenheimer, N. (2004). Cambio de planes a través del tiempo para el traslado de roca en la pampa bonaerense. Estudios Atacameños, 28, 59-70.

Bayón, C., \& Zavala, C. (1994). Coastal sites in southern Buenos Aires: a review of "piedras quebradas". Quaternary of South America and Antarctica Peninsula, 10, 229-254.

Bayón, C., Flegenheimer, N., \& Pupio, A. (2006). Planes sociales en el abastecimiento y traslado de roca en la pampa bonaerense en el Holoceno temprano y tardío. Relaciones de la Sociedad Argentina de Antropología (N. S.), 31, 19-45.

Bayón, C., Flegenheimer, N., Valente, M., \& Pupio, A. (1999). Dime cómo eres y te diré de dónde vienes: La procedencia de rocas cuarcíticas en la Región Pampeana. Relaciones de la Sociedad Argentina de Antropología (N. S.), 24, 187-235.

Beck, C., Taylor, A., Jones, G., Fadem, C., Cook, C., \& Millward, S. (2002). Rocks are heavy: transport costs and palearchaic quarry behavior in the Great Basin. Journal of Anthropological Archaeology, 21, 481507. 
Belardi, J. B. (1992). De lo espacial a lo temporal: Explorando distribuciones de artefactos. Revista de Estudios Regionales, 10, 35-67.

Belardi, J. B., Borrero, L. A., Campan, P., Carballo Marina, F., Franco, N. V., García, M. F., et al. (1992). Intensive archaeological survey in the upper Santa Cruz basin, southern Patagonia. Current Anthropology, $33,451-454$.

Berón, M. (2004). Dinámica poblacional y estrategias de subsistencia de poblaciones prehispánicas de la cuenca Atuel-Salado-Chadileuvú-Curacó, provincia de La Pampa. Unpublished doctoral dissertation. Buenos Aires: Facultad de Filosofía y Letras, Universidad de Buenos Aires.

Berón, M. (2006). Base regional de recursos minerales en el occidente pampeano. Procedencia y estrategias de aprovisionamiento. Relaciones de la Sociedad Argentina de Antropología (N. S.), 31, 47-88.

Berón, M. (2007). Circulación de bienes como indicador de interacción entre las poblaciones de La Pampa occidental y sus vecinos. In C. Bayón, A. Pupio, M. I. González, N. Flegenheimer \& M. Frère M. (Eds.), Arqueología en Las Pampas 1 (pp. 245-264). Buenos Aires: Sociedad Argentina de Antropología.

Berón, M., Curtoni, R., Montalvo, C., Visconti, G., \& Pérez, A. (2002). Arqueología en la laguna de Chillhué (departamento Guatraché, La Pampa, República Argentina). Contribución a la historia de la formación de los territorios. Arqueología, 12, 135-185.

Bevan, A. (2012). Spatial methods for analysing large-scale artefact inventories. Antiquity, 86, 492-506.

Bevan, A., \& Conolly, J. (2009). Modelling spatial heterogeneity and nonstationarity in artifact-rich landscapes. Journal of Archaeological Science, 36, 956-964.

Bhaskar, R. (1975). A realist theory of science (1st ed.). Leeds: Books.

Binford, L. R. (1973). Inter-assemblage variability - the Mousterian and the "functional argument". In C. Renfrew (Ed.), The explanation of culture change: models in prehistory (pp. 227-254). London: University of Pittsburgh Press.

Binford, L. R. (1977). Forty-seven trips. In R. V. S. Wright (Ed.), Stone tools as cultural markers (pp. 24-36). Canberra: Australian Institute of Aboriginal Studies.

Binford, L. R. (1979). Organization and formation processes: looking at curated technologies. Journal of Anthopological Research, 35, 255-273.

Binford, L. R. (1980). Willow smoke and dog's tails: hunter-gatherer settlement system and archaeological site formation. American Antiquity, 45, 4-20.

Binford, L. R. (1981). Behavioral archaeology and the "Pompeii premise". Journal of Anthropological Research, 37, 195-208.

Binford, L. (2001). Constructing frames of reference: an analytical method for archaeological theory building using hunter-gatherer and environmental data sets. Berkeley: University of California Press.

Biró, K. (1998). Stones, numbers - history? The utilization of lithic raw materials in the Middle and Late Neolithic of Hungary. Journal of Anthropological Archaeology, 17, 1-18.

Biró, K., \& Regenye, J. (1991). Prehistoric workshop and exploitation site at Szentgál-Tüzköveshegy. Acta Archaeologica Hungarica, 43, 337-375.

Bishop, R. L. (2012). Sources and sourcing. In D. L. Nichols \& C. A. Pool (Eds.), The Oxford handbook of Mesoamerican archaeology (pp. 579-587). New York: Oxford University Press.

Blades, B. S., \& Adams, B. (2009). Introduction: lithics, landscapes and societies. In B. Adams \& B. S. Blades (Eds.), Lithic materials and palaeolithic societies (pp. ix-xiii). Chichester: Wiley-Blackwell.

Bonomo, M. (2003). Ocupaciones humanas en el litoral maritimo pampeano: Un enfoque arqueológico. Unpublished doctoral dissertation. La Plata: Facultad de Ciencias Naturales y Museo, Universidad Nacional de La Plata.

Bonomo, M. (2005). Costeando las llanuras. Arqueología del litoral marítimo pampeano. Buenos Aires: Sociedad Argentina de Antropología.

Bonomo, M. \& Prates L. (2014). La explotación de depósitos secundarios de rodados en el curso medio del río Negro y el litoral marítimo pampeano. In: P. Escola \& S. Hocsman (Eds.), Artefactos líticos, movilidad y funcionalidad de sitios en Sudamérica. Problemas y perspectivas (pp. 77-92). BAR International Series 2628. Oxford: Archaeopress.

Bonomo, M., Leon, D. C., Turnes, L., \& Apolinaire, E. (2008). Nuevas investigaciones sobre la ocupación prehispánica de la costa pampeana en el Holoceno tardío: El sitio arqueológico Claromecó 1 (partido de Tres Arroyos, provincia de Buenos Aires). Intersecciones en Antropología, 9, 25-41.

Bórmida, M. (n/d). Prolegómenos para una arqueología de la pampa bonaerense. La Plata: Edición Oficial de la Provincia de Buenos Aires, Dirección de Bibliotecas, Museos y Archivos Históricos.

Bórmida, M. (1960). Investigaciones paletnológicas en la región de Bolívar, provincia de Buenos Aires. Anales de la Comisión de Investigaciones Científicas de la Provincia de Buenos Aires, 1, $190-283$. 
Borrero, L. A., Lanata, J. L., \& Ventura, B. N. (1992). Distribuciones de hallazgos aislados en Piedra del Águila. In L. A. Borrero \& J. L. Lanata (Eds.), Análisis espacial en la arqueología patagónica (pp. 9-20). Buenos Aires: Ediciones Ayllu.

Brantingham, P. J. (2003). A neutral model of stone raw material procurement. American Antiquity, 68, 487509.

Brantingham, P. J. (2006). Measuring forager mobility. Current Anthropology, 47, 435-459.

Brantingham, P. J., Olsen, J. W., Rech, J. A., \& Krivoshapkin, A. I. (2000). Raw material quality and prepared core technologies in Northeast Asia. Journal of Archaeological Science, 27, 255-271.

Burger, O., Todd, L. C., \& Burnett, P. (2008). The behavior of surface artifacts: building a landscape taphonomy on the High Plains. In L. L. Scheiber \& B. J. Clark (Eds.), Archaeological landscapes on the High Plains (pp. 203-236). Boulder: University Press of Colorado.

Burrough, P. A. (2001). GIS and geostatistics: essential partners for spatial analysis. Environmental and Ecological Statistics, 8, 361-377.

Burrough, P. A., \& McDonnell, R. A. (1998). Principles of geographical information systems. Oxford: Oxford University Press.

Cardillo, M., \& Scartascini, F. (2007). Tendencias observadas en las estrategias de explotación de recursos líticos en el Golfo de San Matías, provincia de Río Negro, Argentina. In F. Morello, M. Martinic, A. Prieto \& G. Bahamonde (Eds.), Arqueología de Fuego-Patagonia. Levantando piedras, desenterrando huesos... y develando arcanos (pp. 117-127). Punta Arenas: Centro de Estudios del Cuaternario (CEQUA)

Carr, P. J. \& Bradbury, A. P. (2011). Learning from lithics: a perspective on the foundation and future of the organization of technology. PaleoAnthropology (Special Issue), 2011, 305-319.

Carrera Aizpitarte, M. (2007). Estrategias de aprovisionamiento lítico en el área centro-este de la provincia de La Pampa. Unpublished graduate dissertation. Olavarría: Facultad de Ciencias Sociales, Universidad Nacional del Centro de la Provincia de Buenos Aires.

Carrera Aizpitarte, M. (2010). Estrategias de aprovisionamiento lítico en el área centro-este de la Provincia de La Pampa. In M. Berón, L. Luna, M. Bonomo, C. Montalvo, C. Aranda, \& M. Carrera Aizpitarte (Eds.), Mamül Mapu: Pasado y presente desde la arqueología pampeana 2 (pp. 209-224). Ayacucho: Editorial Libros del Espinillo.

Catella, L. (2014). Movilidad y utilización del ambiente en poblaciones cazadoras-recolectoras del sur de la región pampeana: La cuenca del Arroyo Chasicó como caso de estudio. Unpublished doctoral dissertation. La Plata: Facultad de Ciencias Naturales y Museo, Universidad Nacional de La Plata.

Catella, L., Moirano, J., \& Oliva, F. (2010). Disponibilidad de materias primas líticas y su importancia para el análisis del uso del espacio y la organización de la tecnología en sociedades cazadoras recolectoras. In M. Berón, L. Luna, M. Bonomo, C. Montalvo, C. Aranda, \& M. Carrera Aizpitarte (Eds.), Mamül Mapu: Pasado y presente desde la arqueología pampeana 2 (pp. 215-231). Ayacucho: Editorial Libros del Espinillo.

Catella, L., Manassero, M., Moirano, J., \& Oliva, F. (2013). Nuevos aportes al estudio del aprovisionamiento de cuarcita en la Región Pampeana, Argentina. Cuadernos del Instituto Nacional de Antropología y Pensamiento Latinoamericano - Series Especiales, 1(2), 200-215.

Charlin, J. (2002). Aprovisionamiento de materias primas líticas en el NO de la provincia de La Pampa a fines del siglo XIX. In D. Mazzanti, M. Berón \& F. Oliva (Eds.), Del mar a los salitrales. 10.000 años de historia pampeana en el umbral del tercer milenio (pp. 205-218). Mar del Plata: Universidad Nacional de Mar del Plata.

Charlin, J. (2009). Estrategias de aprovisionamiento y utilización de las materias primas líticas en el Campo Volcánico Pali Aike (prov. Santa Cruz, Argentina). BAR International Series 1901. Oxford: Archaeopress.

Chartkoff, J. L. (1995). A nested hierarchy of contexts: an approach to defining significance for lithic scatters. Journal of California and Great Basin Anthropology, 17(1), 28-40.

Chatters, J. (1987). Hunter-gatherer adaptations and assemblage structure. Journal of Anthropological Archaeology, 6, 336-375.

Clark, B. J., \& Scheiber, L. L. (2008). A sloping land: an introduction to archaeological landscapes on the High Plains. In L. L. Scheiber \& B. J. Clark (Eds.), Archaeological landscapes on the High Plains (pp. 116). Boulder: University Press of Colorado.

Close, A. E. (2000). Reconstructing movement in prehistory. Journal of Archaeological Method and Theory, $7,44-77$.

Cole, S. (2005). Toolstone acquisition: Simulation experiments. In Abstracts of the SAA 70th Annual Meeting, Salt Lake City (p. 76). Washington, D.C.: Society for American Archaeology Press.

Collins, M. B. (1975). Lithic technology as a means of processual inference. In E. H. Swanson (Ed.), Lithic technology: making and using stone tools (pp. 15-34). Aldine: Chicago. 
Colombo, M. (2011). El área de abastecimiento de las ortocuarcitas del Grupo Sierras Bayas y las posibles técnicas para su obtención entre los cazadores y recolectores pampeanos. Intersecciones en Antropología, $12,231-243$.

Colombo, M. (2013). Los cazadores recolectores pampeanos y sus rocas. La obtención de materias primas líticas vista desde las canteras arqueológicas del centro de Tandilia. Unpublished doctoral dissertation. La Plata: Facultad de Ciencias Naturales y Museo, Universidad Nacional de La Plata.

Conolly, J., \& Lake, M. (2006). Geographical information systems in archaeology. Cambridge: Cambridge University Press.

Contaminated Sites Statistical Applications Guidance. (2001). Estimating a global mean a guide for data analysts and interpreters on the estimation of an average contaminant concentration over a large area or volume. Contaminated Sites Statistical Applications Guidance Document, 12-9, 1-4.

Crivelli Montero, E. A., Eugenio, E. O., Pardiñas, U. F. J., \& Silveira, M. J. (1994). Archaeological investigation in the plains of the province of Buenos Aires, Llanura Interserrana Bonaerense. Quaternary of South America \& Antarctic Peninsula, 10, 167-209.

Curtoni, R. (1999). Aprovisionamiento de materia prima y técnica de reducción bipolar en un ambiente semidesértico. In Soplando en el Viento. Actas de las Terceras Jornadas de Arqueología de la Patagonia (pp. 165-176). Buenos Aires-Neuquén: Instituto Nacional de Antropología y Pensamiento Latinoamericano y Universidad Nacional del Comahue.

Dalla Salda, L., Saplletti, L., de Poiré, D., Barrio, R., Echeveste, H., \& Benialgo, A. (2006). Tandilia. Serie Correlación Geológica, 21(1), 17-46.

Darvill, T. (2008). The concise Oxford dictionary of archaeology (2nd ed.). New York: Oxford University Press.

Delcourt, H., \& Delcourt, P. (1988). Quarternary landscape ecology: relevant scales in space and time. Landscape Ecology, 2, 23-44.

Dincauze, D. (2000). Environmental archaeology: principles and practice. Cambridge: Cambridge University Press.

Dixon, P. (2002). Ripley's K function. In A. El-Shaarawi \& W. Piergorsh (Eds.), Encyclopedia of environmetrics 3 (pp. 1796-1803). Chichester: Wiley.

Doelman, T. (2008). Time to quarry: the archaeology of stone procurement in northwestern New South Wales, Australia. BAR International Series 1801. Oxford: Archaeopress.

Driesch, H. (1929). The science and philosophy of the organism. London: Black.

Dunnell, R. C., \& Dancey, W. (1983). The siteless survey: a regional scale data collection strategy. Advances in Archaeological Method and Theory, 6, 267-287.

Ebert, D. (2004). Applications of archaeological GIS. Canadian Journal of Archaeology, 28, 319-341.

Ebert, J. I. (1992). Distributional archaeology. Albuquerque: University of New Mexico Press.

Ebert, J. I., \& Kohler, T. (1988). The theoretical basis of archaeological predictive modeling and a consideration of appropriate data-collection methods. In W. J. Judge \& L. Sebastian (Eds.), Quantifying the present and predicting the past: theory, method and application of archaeological predictive modeling (pp. 97-123). Denver: U. S. Department of the Interior, Bureau of Land Management.

Elburg, R. \& van der Kroft, P. (2006). Of lithic territories, ancient and modern. In C. Bressy, A. Burke, P. Chalard \& H. Martin (Dirs.), Notions de territoire et de mobilité. Exemples de l'Europe et des premières nations en Amérique du Nord avant le contact européen (pp. 151-154). ERAUL 116. Liege: Université de Liège.

Elissalde, B. \& Saint-Julien, T. (2004). Spatial structure. Hypergeo http://www.hypergeo.eu/spip.php? article210. Accessed 25 Jun 2011.

Elston, R. G. (1992). Archaeological research in the context of cultural resource management: pushing back in the 1990s. Journal of California and Great Basin Anthropology, 14(1), 37-48.

English Heritage. (2000). Managing lithic scatters. Archaeological guidance for planning authorities and developers. London: Billington Press.

Ericson, J. E. (1977). Egalitarian exchange systems in California: a preliminary view. In T. K. Earle \& J. E. Ericson (Eds.), Exchange systems in prehistory (pp. 109-126). New York: Academic.

Ericson, J. E. (1984). Toward the analysis of lithic reduction systems. In J. E. Ericson \& B. Purdy (Eds.), Prehistoric quarries and lithic production (pp. 11-22). Cambridge: Cambridge University Press.

Ericson, J. E., \& Purdy, B. A. (Eds.). (1984). Prehistoric quarries and lithic production. Cambridge: Cambridge University Press.

Eugenio, E. \& Aldazabal, V. (1987-1988). El sitio arqueológico de Laguna de Sotelo, Pdo. de Mar Chiquita, Pcia. de Bs. As. Paleoetnológica, 4, 79-86.

Eugenio, E. \& Aldazábal, V. (2004). Los cazadores recolectores del litoral marítimo del área de Bahía de San Blas, Provincia de Buenos Aires. In M. T. Civalero, P. M. Fernández \& A. G. Guráieb (Comps.), Contra 
viento y marea. Arqueología de Patagonia (pp. 687-700). Buenos Aires: Instituto Nacional de Antropología y Pensamiento Latinoamericano, Sociedad Argentina de Antropología.

Eugenio, E., Aldazábal, V., \& Silveira, M. J. (2007). El yacimiento arqueológico La Raquel 2. Partido de Gral. La Madrid, Buenos Aires. In F. Oliva, N. de Grandis, \& J. Rodríguez (Eds.), Arqueología argentina en los inicios de un nuevo siglo 1 (pp. 239-250). Rosario: Laborde.

Féblot-Augustins, J. (1993). Mobility strategies in the late middle Palaeolithic of central Europe and western Europe: elements of stability and variability. Journal of Anthropological Archaeology, 12, 211-265.

Féblot-Augustins, J. (1997). La circulation des matières premières au Paléolithique. Synthèse des donnèes, perspectives comportementales. ERAUL 75. Liege: Université de Liège.

Féblot-Augustins, J. (2009). Revisiting European Upper Palaeolithic raw material transfers: the demise of the cultural ecological paradigm? In B. Adams \& B. S. Blades (Eds.), Lithic materials and paleolithic societies (pp. 25-46). Chichester: Wiley-Blackwell.

Fennell, C. C. (Comp.). (2010). Revealing landscapes. Perspectives from historical archaeology 5. Urbana: The Society for Historical Archaeology, University of Illinois

Ferring, C. (1986). Rates of fluvial sedimentation: implications for archaeological variability. Geoarchaeology, 1(3), 259-274.

Fidalgo, F., \& Riggi, J. C. (1965). Los rodados patagónicos en la Meseta de Guenguel y alrededores. Revista de la Asociación Geológica Argentina, 20, 273-325.

Fidalgo, F., \& Riggi, J. C. (1970). Consideraciones geomorfológicas y sedimentológicas sobre los rodados patagónicos. Revista de la Asociación Geológica Argentina, 25, 430-443.

Findlow, F. J., \& Bolognese, M. (1982). Regional modeling of obsidian procurement in the American Southwest. In J. E. Ericson \& T. K. Earle (Eds.), Contexts for exchange (pp. 53-81). New York: Academic.

Flegenheimer, N. (1991). La Liebre, un sitio cantera-taller. Boletín del Centro, 2, 58-64.

Flegenheimer, N. \& C. Bayón (2002). Cómo, cuándo y dónde? Estrategias de abastecimiento lítico en la pampa bonaerense. In D. Mazzanti, M. Berón M. \& F. Oliva (Eds.), Del mar a los salitrales. Diez mil años de historia pampeana en el umbral del tercer milenio (pp. 231-241). Mar del Plata: Universidad Nacional de Mar del Plata and Sociedad Argentina de Antropología.

Flegenheimer, N., Kain, C., Zárate, M., \& Barna, A. (1996). Aprovisionamiento de cuarcitas en Tandilia, las canteras de arroyo Diamante. Arqueología, 6, 117-141.

Flegenheimer, N., Bayón, C., Valente, N., Baeza, J., \& Femenías, J. (2003). Long distance tools transport in the Argentine Pampas. Quaternary International, 109-110, 49-64.

Foley, R. (1981). Off-site archaeology and human adaptation in eastern Africa. An analysis of regional artefact density in the Amboseli, southern Kenia. Cambridge Monographs in African Archaeology 3. BAR International Series 97. Oxford: Oxbow.

Fulford, M. G., \& Hodder, I. (1974). A regression analysis of some Late Romano-British pottery: a case study. Oxoniensia, 39, 26-33.

Franco, N. V., \& Borrero, L. A. (1999). Metodología de análisis de la estructura regional de recursos líticos. In C. A. Aschero, M. A. Korstanje, \& P. M. Vuoto (Eds.), En los tres reinos: Prácticas de recolección en el cono sur de América (pp. 27-37). San Miguel de Tucumán: Ediciones Magna Publicaciones.

French, F., \& Saatsi, J. (2011). The Continuum companion to the philosophy of science. London: Continuum. Frenguelli, J. (1931). Nomenclatura estratigráfica patagónica. Anales de la Sociedad de Ciencias de Santa Fe, $3,1-115$.

Gavilán, M. E., Scarafia, G., Tamburini, D., \& Carletti, S. (2004). Análisis tecnotipológico de los desechos de talla lítica del sitio Laguna Las Tunas Grandes. Trenque Lauquen, provincia de Buenos Aires. In C. Gradín \& F. Oliva (Eds.), La Región Pampeana -Su pasado arqueológico (pp. 389-399). Rosario: Laborde Editor.

Gibbon, G. (1984). Anthropological archaeology. New York: Columbia University Press.

González de Bonaveri, M. I., Frère, M., Bayon, C., \& Flegenheimer, N. (1999). La organización de la tecnología en la cuenca del Salado. Arqueología, 8, 57-76.

Gould, R. A., \& Saggers, S. (1985). Lithic procurement in central Australia: a closer look at Binford's idea of embeddedness in archaeology. American Antiquity, 50, 117-135.

Gradín, C. (Ed.). (1984). Investigaciones arqueológicas en Casa de Piedra. Santa Rosa: Dirección General y Ente Ejecutivo Casa de Piedra.

Graf, K. E. (2010). Hunter-gatherer dispersals in the mammoth-steppe: technological provisioning and landuse in the Yenisei River valley, south-central Siberia. Journal of Archaeological Science, 37, $210-223$.

Greber, N. (1976). Within Ohio Hopewell: analyses of burial patterns from several classic sites. Unpublished doctoral dissertation. Cleveland: Department of Anthropology, Case Western Reserve University. 
Grove, M. (2010). The quantitative analysis of mobility: ecological techniques and archaeological extensions. In S. Lycett \& P. Chuahan (Eds.), New perspectives on old stones: analytical approaches to palaeolithic technologies (pp. 83-118). NewYork: Springer.

Haggett, P. (1965). Locational analysis in human geography. London: Arnold.

Harrington, H. J. (1947). Explicación de las Hojas Geológicas 33m y 34m Sierras Australes de Curamalal y de la Ventana, Prov. de Buenos Aires. Boletín de la Dirección de Minas y Geología, 61, 5-43.

Harro, D. R. (1997). Patterns of lithic raw material procurement on the Pajarito Plateau, New Mexico. Unpublished master's dissertation. Pullman: Department of Anthropology, Washington State University.

Heaton, J. (2004). Reworking qualitative data. London: Sage.

Hodder, I. (1978). The spatial organization of culture. London: Duckworth.

Hodder, I., \& Orton, C. (1976). Spatial analysis in archaeology. Cambridge: Cambridge University Press.

Holdaway, S., Fanning, P., \& Rhodes, E. (2008). Assemblage accumulation as a time-dependent process in the arid zone of western New South Wales, Australia. In S. Holdaway \& L. Wandsnider (Eds.), Time in archaeology. Time perspectivism revisited (pp. 110-133). Ann Arbor: The University of Utah Press.

Holdaway, S., Douglass, M. \& Fanning, P. (2012). Landscape scale and human mobility: geoarchaeological evidence from Rutherfords Creek, New South Wales, Australia. In S. J. Kluiving \& E. B. Guttmann-Bond (Eds.), Landscape archaeology between art and science. From a multi- to an interdisciplinary approach (pp. 279-294). Amsterdam : Amsterdam University Press.

Hu, D. (2011). Advancing theory?: landscape archaeology and geographical information systems. Papers of the Institute of Archaeology, 21, 80-90.

Ingbar, E. E. (1994). Lithic material selection and technological organization. In P. J. Carr (Ed.), The organization of North American prehistoric chipped stone tool technologies (pp. 45-56). Archaeological Series 7. Ann Arbor: International Monographs in Prehistory.

Jeske, R. (1992). Energetic efficiency and lithic technology: an upper Mississippian example. American Antiquity, 57, 467-481.

Jiang, B. (2010). Scaling of geographic space and its implications. Paper presented at Las Navas 20th Anniversary Meeting on Cognitive and Linguistic Aspects of Geographic Space, Las Navas del Marques, Avila, Spain. http://fromto.hig.se/ bjg/PositionPaper11PDF.pdf. Accessed 7 Nov 2012.

Johnston, K., Ver Hoef, J. M., Krivoruchko, K., \& Lucas, N. (2001). Using ArcGIS geostatistical analyst. Redlands: ESRI.

Journel, A. G. (1983). Nonparametric estimation of spatial distributions. Journal of the International Association for Mathematical Geology, 15(3), 445-468.

Kaufmann, C. A. \& Messineo, P. G. (2010). Investigaciones arqueológicas en el sitio El Puente. Una ocupación indígena en las Sierras Bayas (partido de Olavarría, Buenos Aires). Newsletter 15. http:// www.soc.unicen.edu.ar/newsletter/n15/kaffman_messineo.html. Accessed 11 Jul 2013.

Kelly, R. L. (1988). The three sides of a biface. American Antiquity, 53, 717-734.

Kelly, R. L. (1992). Mobility/sedentism concepts: archaeological measures, and effects. Annual Review of Anthropology, 21, 43-66.

Kelly, R. L., \& Thomas, D. H. (2009). Archaeology (5th ed.). Belmont: Wadsworth.

Kooyman, B. P. (2000). Understanding stone tools and archaeological sites. Calgary: University of Calgary Press.

Kostadinoff, J. (2007). Evidencia geofísica del umbral de Trenque Lauquen en la extensión norte de la cuenca de Claromecó, provincia de Buenos Aires. Revista de la Asociación Geológica Argentina, 62(1), 1-10.

Kuhn, S. (1991). Unpacking reduction: lithic raw material economy in the Mousterian of west-central Italy. Journal of Anthropological Archaeology, 10, 76-106.

Khun, S. (1995). Mousterian lithic technology. An ecological perspective. Princeton: Princeton University Press.

Kuhn, S. (2004). Upper Paleolithic raw material economies at Üçagizli Cave, Turkey. Journal of Anthropological Archaeology, 23, 431-448.

Laylander, D. (2005). Obsidian studies and Baja California's prehistory. Memorias 2005-2011, Encuentro Binacional Balances y Perspecivas. http://www.xaguaro.com/MemoriasCD/page1/styled-2/page12/ page12.html. Accessed 10 Jul 2014.

Leipus, M. (2006). Análisis de los modos de uso prehispánicos de las materias primas líticas en el sudeste de la Región Pampeana. Una aproximación Funcional. Unpublished doctoral dissertation. La Plata: Facultad de Ciencias Naturales y Museo, Universidad Nacional de La Plata.

Linares, E., Llambías, E., \& Latorre, C. (1980). Geología de la provincia de La Pampa, República Argentina y geocronología de sus rocas metamórficas y eruptivas. Revista de la Asociación Geológica Argentina, $35(1), 87-146$. 
Lloyd, C. D., \& Atkinson, P. M. (2004). Archaeology and geostatistics. Journal of Archaeological Science, 31, $151-165$.

Loponte, D. (1987). Tecnotipologías de Costa Bonita. Estudios en Antropología Pampeana, 2, 22-35.

Lozano, P. (1991). Cerro Aguirre: Un sitio de aprovisionamiento de materias primas líticas en la localidad de Sierras Bayas (pcia. de Buenos Aires). Shincal, 3(3), 145-150.

Luedtke, B. (1979). The identification of sources of chert artifacts. American Antiquity, 44, 744-756.

Lyman, R. L. (2004). The concept of equifinality in taphonomy. Journal of Taphonomy, 2(1), 15-26.

Madella, M., Rondelli, B., Lancelotti, C., Balbo, A., Zurro, D., Campillo, R., et al. (2014). Introduction to simulating the past. Journal of Archaeological Method and Theory, 21, 251-257.

Madrazo, G. (1972). Arqueología de Lobería y Salliqueló (pcia. de Buenos Aires). Etnía, 15, 1-18.

Madrid, P., \& Politis, G. (1991). Estudios paleoambientales en la Región Pampeana: Un enfoque multidisciplinario del sitio La Toma. In H. Niemeyer Fernández (Ed.), Actas del XI Congreso Nacional de Arqueología Chilena 1 (pp. 131-152). Santiago de Chile: Museo Nacional de Historia Natural y Sociedad Chilena de Arqueología.

Madrid, P., Politis, G., Leipus, M., \& Landini, C. (1991). Estado actual de las investigaciones en el sitio 1 de la laguna Tres Reyes: Análisis lítico tecno-morfológico y procesos de formación del sitio. Boletín del Centro, 2, 112-122.

Madrid, P., Politis, G., March, R., \& Bonomo, M. (2002). Arqueología microregional en el sudeste de la Región Pampeana Argentina: El curso del río Quequén Salado. Relaciones de la Sociedad Argentina de Antropología (N. S.), 27, 327-355.

Martínez, G. (1999). Tecnología, subsistencia y asentamiento en el curso medio del río Quequén Grande: Un enfoque arqueológico. Unpublished doctoral dissertation. La Plata: Facultad de Ciencias Naturales y Museo, Universidad Nacional de La Plata.

Martínez, G. (2004). Resultados preliminares de las investigaciones arqueológicas realizadas en el curso inferior del Río Colorado (partidos de Villarino y Patagones, provincia de Buenos Aires). In G. Martínez, M. Gutiérrez, R. Curtoni, M. Berón \& P. Madrid (Eds.), Aproximaciones contemporáneas a la arqueología pampeana. Perspectivas teóricas, metodológicas, analíticas y casos de estudio (pp. 275292). Olavarría: Facultad de Ciencias Sociales, Universidad Nacional del Centro de la Provincia de Buenos Aires.

Martínez, G. (2008). Arqueología del curso inferior del río Colorado: Estado actual del conocimiento e implicaciones para la dinámica poblacional de cazadores-recolectores pampeano-patagónicos. CazadoresRecolectores del Cono Sur, Revista de Arqueología, 3, 71-92.

Martínez, G., \& Mackie, Q. (2003). Late Holocene human occupation of the Quequén Grande river valley bottom: settlement systems and an example of a built environment in the Argentine pampas. Before farming: the archaeology and anthropology of hunter-gatherers, 2003/4 (1). http://www.waspress.co.uk/ journals/beforefarming/journal_20034/abstracts/papers/20034_01.pdf. Accessed 22 Jan 2013.

Martínez, G., Flensborg, G., \& Bayala, P. (2012). Human corpse manipulation and the body as symbols: a case study from de Eastern Pampa-Patagonia transition (Argentina) during the Final Late Holocene. Journal of Anthropological Archaeology, 31, 215-226.

Martínez, G., Armentano, G., Stoessel, L., Martínez, G.A., Alcaráz, A.P., González, N. \& Santos, F. (2010). Resultados preliminares de la localidad arqueológica San Antonio (curso inferior del río Colorado, pdo. de Villarino, pcia. de Buenos Aires). In M. Berón, L. Luna, M. Bonomo, C. Montalvo, C. Aranda \& M. Carrera Aizpitarte (Eds.), Mamül Mapu: Pasado y presente desde la arqueología pampeana 2 (pp. 241252). Ayacucho: Editorial Libros del Espinillo.

Martínez, O., Rabassa, J., \& Coronato, A. (2009). Charles Darwin and the first scientific observations on the Patagonian Shingle Formation (Rodados Patagónicos). Revista de la Asociación Geológica Argentina, 64(1), 90-100.

Massigoge, A. (2007). Resultados preliminares de las investigaciones arqueológicas desarrolladas en el partido de San Cayetano (provincia de Buenos Aires). In C. Bayón, A. Pupio, M. I. González, N. Flegenheimer, \& M. Frère (Eds.), Arqueología en las Pampas 2 (pp. 511-534). Sociedad Argentina de Antropología: Buenos Aires.

Massigoge, A., \& Pal, N. (2011). Producción y uso de artefactos líticos en contextos cazadores-recolectores del Área Interserrana (Argentina): Análisis integral de la diversidad tecno-morfológica y funcional. Revista Española de Antropología Americana, 41(1), 51-73.

Matarrese, A. B., \& Poiré, D. G. (2009). Rocas para moler: análisis de procedencia de materias primas líticas para artefactos de molienda (Área Interserrana Bonaerense). Intersecciones en Antropología, 10, 121140.

Mazzanti, D. (1997). Excavaciones arqueológicas en el sitio Cueva Tixi, Buenos Aires, Argentina. Latin American Antiquity, 8, 55-62. 
Mazzia, N., \& Flegenheimer, N. (2007). Retorno a La China: Una visión de las ocupaciones tardías. In C. Bayón, A. Pupio, M. I. González, N. Flegenheimer, \& M. Frère (Eds.), Arqueología en Las Pampas 2 (pp. 549-566). Buenos Aires: Sociedad Argentina de Antropología.

McCoy, M. D., Ladefoged, T. N., Blanshard, A., \& Jorgensen, A. (2010). Reconstructing lithic supply zones and procurement areas: an example from the Bay of Islands, Northland, New Zealand. Journal of Pacific Archaeology, 1, 174-183.

Messineo, P. G., \& D’Augerot, L. (2004). Análisis preliminares de los materiales líticos provenientes de la Laguna Blanca Chica (Olavarría, Buenos Aires). Intersecciones en Antropología, 5, 187-190.

Messineo, P. G., Barros, M. P., Poiré, D. G. \& Gómez Peral, L. (2004). Características litológicas de los niveles de chert o ftanitas en las Sierras Bayas (pdo. de Olavarría, pcia. de Buenos Aires). In G. Martínez, M. Gutiérrez, R. Curtoni, M. Berón \& P. Madrid (Eds.), Aproximaciones contemporáneas a la arqueología pampeana. Perspectivas teóricas, metodológicas, analíticas y casos de estudio (pp. 307319). Olavarría: Facultad de Ciencias Sociales, Universidad Nacional del Centro de la Provincia de Buenos Aires.

Messineo, P. G., Barros, M. P., Pérez, J. \& Piccione, G. (2009). Cerro Tres Lomas 1: Una cantera-taller de dolomía silicificada en las sierras de Olavarría (provincia de Buenos Aires). In A. Austral \& M. Tamagnini, M. (Comps.), Problemática de la arqueología contemporánea 3 (pp. 593-599). Río Cuarto: Universidad Nacional de Río Cuarto.

Milillo, T. M. \& Gardella III, J. A. (2005). Spatial statistics and interpolation methods for TOF SIMS Imaging. Paper presented at the 15th International Conference on Secondary Ion Mass Spectrometry (SIMS XV), Manchester. http:/www.simssociety.org/SIMSXV/Papers/DIS-O-Th-A08\%20Gardella\%20et\%20al.pdf. Accessed 12 Apr 2013.

Miller, H. J. (2004). Tobler's first law and spatial analysis. Annals of the Association of American Geographers, 94, 284-289.

Moirano, J. (1999). Aprovisionamiento de recursos líticos y variabilidad artefactual en el sur de la Subregión Pampa Húmeda: La revisión de las colecciones particulares. Relaciones de la Sociedad Argentina de Antropología (N. S.), 24, 237-256.

Mullett, A. N. (2009). Paleoindian mobility ranges predicted by the distribution of projectile points made of Upper Mercer and Flint Ridge flint. Unpublished master's dissertation. Kent: Department of Anthropology, Kent State University.

Mullett, A. N. (2012). An assessment of the accuracy of interpolation methods for estimating early Paleoindian mobility patterns. Abstract AAG Annual Meeting. http://meridian.aag.org/callforpapers/program/ AbstractDetail.cfm?AbstractID=46864. Accessed 11 Jul 2013.

Nelson, M. C. (1991). The study of technological organization. In M. B. Schiffer (Ed.), Archaeological method and theory (pp. 57-100). Tucson: University of Arizona Press.

Nerlich, G. (1979). What can geometry explain? British Journal for the Philosophy of Science, 30, 69-83.

Odell, G. H. (2004). Lithic analysis. New York: Kluwer Academic/Plenum.

Oliva, F. (2014). Investigaciones arqueológicas en el sector centro-occidental de la Sierra de la Ventana y la llanura adyacente. Unfinished Doctoral Dissertation. La Plata: Facultad de Ciencias Naturales y Museo, Universidad Nacional de La Plata.

Oliva, F., \& Moirano, J. (1997). Primer informe sobre aprovisionamiento primario de riolita en Sierra de La Ventana. In M. Berón \& G. Politis (Eds.), Arqueología pampeana en la década de los '90 (pp. 137-146). San Rafael: Museo de Historia Natural de San Rafael.

Oliva, F. \& Perez, I. (2008). Análisis cuantitativo de "reservorios" o "caches" de artefactos y materias primas líticas de sitios del borde occidental de la Pampa Húmeda. In A. Austral \& M. Tamagnini, M. (Comps.), Problemáticas de la arqueología contemporánea 2 (pp. 345-354). Río Cuarto: Universidad Nacional de Río Cuarto.

Oliva, F., Moirano, J., \& Saghessi, M. (1991). Estado de las investigaciones en el sitio Laguna de Puan 1. Boletín del Centro, 2, 127-138.

Oliva, F., Avila, J., Ayuso, M., Catella, L., \& Gallego, M. (2006). Investigaciones arqueológicas en la cuenca del arroyo Chasicó y llanura adyacente, sudoeste de la provincia de Buenos Aires. Comechingonia, Revista de Arqueología, 9, 123-139.

Oliva, F., L'Heureux, G., De Angelis, H., Parmigiani, V. \& Reyes, F. (2007). Poblaciones indígenas de momentos post-contacto en el borde occidental de la Pampa Húmeda: Gascón 1, un sitio de entierros humanos. In F. Oliva, N. de Grandis \& J. Rodríguez (Eds.), Arqueología argentina en los inicios de un nuevo siglo 1 (pp. 265-274). Rosario: Laborde Editor.

Ortega, D., Ibañez, J. J., Khalidi, L., Méndez, V., Campos, D., \& Teira, L. (2014). Towards a multi-agentbased modelling of obsidian exchange in the Neolithic Near East. Journal of Archaeological Method and Theory, 21, 461-485. 
Outes, F. (1907). Arqueología de San Blas (provincia de Buenos Aires). Anales del Museo Nacional de Buenos Aires, 16, 249-273.

Pal, N. (2007). Estudio tecnomorfológico de los microdesechos líticos del sitio Laguna La Barrancosa 1 (Partido de Benito Juárez, Provincia de Buenos Aires). In C. Bayón, A. Pupio, M. I. González, N. Flegenheimer, \& M. Frère (Eds.), Arqueología en las Pampas 1 (pp. 217-231). Buenos Aires: Sociedad Argentina de Antropología.

Pardo-Iguzquiza, E., \& Chica-Olmo, M. (2008). Geostatistics with the Matern semivariogram model: a library of computer programs for inference, kriging and simulation. Computers \& Geosciences, 34(9), 10731079 .

Patton, M. Q. (2002). Qualitative research and evaluation methods (3rd ed.). Thousand Oaks: Sage.

Phillips, S. C. (2011). Networked glass: lithic raw material consumption and social networks in the Kuril Islands, far eastern Russia. Unpublished doctoral dissertation. Seattle: University of Washington. https:// digital.lib.washington.edu/.../handle/.../16354. Accessed 11 Jul 2014.

Pitblado, B. L., Cannon, M. B., Neff, H., Dehler, C. M., \& Nelson, S. T. (2013). LA-ICP-MS analysis of quartzite from the Upper Gunnison Basin, Colorado. Journal of Archaeological Science, 40, 2196-2216.

Politis, G., \& Madrid, P. (2001). Arqueología pampeana: estado actual y perspectivas. In E. Berberián \& A. Nielsen (Eds.), Historia argentina prehispánica 2 (pp. 737-814). Córdoba: Editorial Brujas.

Politis, G., Martínez, G., \& Bonomo, M. (2004). Revisión del sitio Zanjón Seco 2 (Área Interserrana Bonaerense) en base a nuevos datos y análisis. In C. Gradín \& F. Oliva (Eds.), La Región Pampeana, su pasado arqueológico (pp. 73-88). Rosario: Laborde Editor.

Prates, L. (2008). Los indígenas del río Negro. Un enfoque arqueológico. Buenos Aires: Sociedad Argentina de Antropología.

Prates, L., Di Prado, V., Mange, E., \& Serna, A. (2010). Sitio Loma de los Muertos. Múltiples ocupaciones sobre un médano del este de Nordpatagonia (Argentina). Magallania, 38(1), 165-181.

Premo, L. S. (2010). On the role of agent-based modeling in post-positivist archaeology. In A. Costopoulos \& M. Lake (Eds.), Simulating change: archaeology into the 21st century (pp. 28-37). Salt Lake City: University of Utah Press.

Reid, P. (1986). Models for prehistoric exchange in the Middle Great Lakes' Basin. Ontario Archaeology, 46, 33-44.

Renfrew, C. (1972). The emergence of civilisation - the Cyclades and the Aegean in the Third Millennium BC. London: Methuen.

Renfrew, C. (1975). Trade as action at a distance: questions of integration and communication. In J. A. Sabloff \& C. C. Lamberg-Karlovsky (Eds.), Ancient civilization and trade (pp. 3-36). Albuquerque: University of New Mexico Press.

Renfrew, C. (1977). Alternative models for exchange and spatial distribution. In T. K. Earle \& J. E. Ericson (Eds.), Exchange systems in prehistory (pp. 71-90). New York: Academic.

Renfrew, C., Dixon, J. E. \& Cann, J. R. (1968). Further analysis of Near East obsidian. Proceedings of the Prehistoric Society, 34, 319-331.

Robins, R. (1997). Patterns in the landscape: a case study on non-site archaeology from southwest Queensland. Memoirs of the Queensland Museum, Cultural Heritage Series, 1, 23-56.

Roebroeks, W., Kolen, J., \& Rensink, E. (1988). Planning depth, anticipation and the organization of Middle Palaeolithic technology: the "archaic natives" meet Eve's descendants. Helinium, 28(1), 17-34.

Rogers, A. R. (2000). On equifinality in faunal analysis. American Antiquity, 65, 709-723.

Rouse, I. (1972). Settlement patterns in archaeology. In P. Ucko, R. Tringham, \& D. W. Dimbleby (Eds.), Man, settlement and urbanism (pp. 95-107). London: Duckworth.

Saghessi, M., \& Petz, R. (2007). Estudio del material lítico del área de Las Encadenadas. partido de Guaminí (provincia de Buenos Aires). In F. Oliva, N. de Grandis, \& J. Rodríguez (Eds.), Arqueología argentina en los inicios de un nuevo siglo 1 (pp. 615-620). Rosario: Laborde Editor.

Salmon, N. (1984). Scientific explanation and the causal structure of the world. Princeton: Princeton University Press.

Shelford, P., Hodson, F., Cosgrove, M. E., Warren, S. E., \& Renfrew, C. (1982). The sources and characterisation of Melian obsidian. In C. Renfrew \& J. M. Wagstaff (Eds.), An island polity: the archaeology and exploitation on Melos (pp. 182-192). Cambridge: Cambridge University Press.

Shott, M. J. (Ed.). (2006). Formation theory in archaeology: readings from American antiquity and Latin American antiquity. Washington: Society for American Archaeology Press.

Shott, M. J. (2010). Lithic landscapes and raw-material exploitation by hunter-gatherers. Review of "Estrategias de aprovisionamiento y utilización de las materias primas líticas en el Campo Volcánico Pali Aike (prov. Santa Cruz, Argentina). Judith E. Charlin. BAR International Series 1901. 2009. Oxford, UK. vii251pp.". Intersecciones en Antropología, 11, 326-332. 
Skarbun, F. \& Frank A. D. (2011). Organización espacial intrasitio durante el Pleistoceno final en la Meseta Central de Santa Cruz. Evidencias del sitio Casa del Minero 1. Relaciones de la Sociedad Argentina de Antropología (N. S.), 36, 289-313.

Skow, B. (2013). Are there non-causal explanations (of particular events)? The British Journal for the Philosophy of Science. doi:10.1093/bjps/axs047.

Sober, E. (1983). Equilibrium explanation. Philosophical Studies, 43, 201-210.

Soja, E. (1971). The political organization of space. Resource Paper 8, Association of American Geographers. Seattle: Northwestern University.

Stark, B. L., \& Garraty, C. P. (2010). Detecting marketplace exchange in archaeology: a methodological review. In C. P. Garraty \& B. L. Stark (Eds.), Archaeological approaches to market exchange in ancient societies (pp. 33-60). Boulder: University Press of Colorado.

Stoyan, D., \& Stoyan, S. (1994). Fractals, random shapes and point fields. Methods of geometrical statistics. Chichester: Wiley.

Strevens, M. (2008). Depth: an account of scientific explanation. Cambridge: Harvard University Press.

Surovell, T. A. (2003). The behavioral ecology of Folsom lithic technology. Unpublished doctoral dissertation. Tucson: University of Arizona. http://arizona.openrepository.com/arizona/bitstream/10150/289958/1/ azu_td_3107044_sip1_m.pdf. Accessed 11 Jun 2013.

Teltser, P. (1995). The methodological challenge of evolutionary theory in archaeology. In P. Teltser (Ed.), Evolutionary archaeology. Methodological issues (pp. 1-12). Tucson: The University of Arizona Press.

Thomas, D. (1975). Nonsite sampling in archaeology: up the creek without a site? In J. W. Mueller (Ed.), Sampling in archaeology (pp. 61-81). Tucson: The University of Arizona Press.

Tobler, W. R. (1970). A computer movie simulating urban growth in the Detroit region. Economic Geography, 46, 234-240.

Topping, P., \& Lynott, M. (Eds.). (2005). The cultural landscapes of prehistoric mines. Oxford: Oxbow Books.

Torrence, R. (1986). Production and exchange of stone tools. Cambridge: Cambridge University Press.

Torrence, R. (1989). Tools as optimal solutions. In R. Torrence (Ed.), Time, energy and stone tools (pp. 1-6). Cambridge: Cambridge University Press.

Tripcevich, N. (2007). Quarries, caravans, and routes to complexity: prehispanic obsidian in the south-central Andes. Unpublished doctoral dissertation, Santa Barbara: University of California. http://works.bepress. com/tripcevich/8/. Accessed 15 May 2013.

Turchin, P. (2003). Historical dynamics: why states rise and fall. Princeton: Princeton University Press.

Turchin, P. (2006). Comments on "Measuring forager mobility" by J. P. Brantingham. Current Anthropology, $47,453-454$.

Valverde, F. (2002). Variabilidad de recursos líticos en dos sitios paleoindios de las sierras de Tandilia oriental, provincia de Buenos Aires. In D. Mazzanti, M. Berón \& F. Oliva (Eds.), Del mar a los salitrales. Diez mil años de historia pampeana en el umbral del tercer milenio (pp. 281-287). Mar del Plata: Universidad Nacional de Mar del Plata.

Verhagen, P., \& Whitley, T. G. (2012). Integrating archaeological theory and predictive modeling: a live report from the scene. Journal of Archaeological Method and Theory, 19, 49-100.

Villatoro, M., Henríquez, C., \& Sancho, F. (2008). Comparación de los interpoladores IDW y Kriging en la variación espacial del pH, Ca, CICE, y P del suelo. Agronomía Costarricense, 32, 95-105.

von Bertalanffy, L. (1950). The theory of open systems in physics and biology. Science, 111, 23-29.

Von Thünen, J. H. (1966). The isolated state. New York: Pergamon.

Wandsnider, L. (1992). Archaeological landscape studies. In J. Rossignol \& L. Wandsnider (Eds.), Space, time and archaeological landscapes (pp. 285-292). New York: Plenum.

Wandsnider, L. (1998). Landscape element configuration, lifespace and occupation history: Ethnoarchaeological observations and archaeological applications. In A. P. Sullivan III (Ed.), Surface archaeology (pp. 21-38). Albuquerque: University of New Mexico Press.

Wandsnider, L. (2003). Solving the puzzle of the archaeological labyrinth: time perspectivism in Mediterranean surface archaeology. In S. Alcock \& J. Cherry (Eds.), Side-by-side survey: comparative regional studies in the Mediterranean world (pp. 49-62). Oxford: Oxbow Press.

Webb, K. (1993). The lithification of a sandy environment. Archaeology in Oceania, 28, 105-111.

Weisberg, H. I. (2010). Bias and causation: models and judgment for valid comparisons. Hoboken: Wiley.

Wilson, L. (2003). Importance de la difficulté du terrain par rapport à la distance de transport dans les stratégies de circulation des matières premières lithiques dans le Vaucluse, au Paléolithique moyen. Préhistoire du Sud-Ouest, Supplément, 5, 343-349.

Wilson, L. (2007a). Terrain difficulty as a factor in raw material procurement in the middle Palaeolithic of France. Journal of Field Archaeology, 32, 315-324. 
Wilson, L. (2007b). Understanding prehistoric lithic raw material selection: application of a gravity model. Journal of Archaeological Method and Theory, 14, 388-411.

Wilson, L. (2011). The role of geoarchaeology in extending our perspective. Geological Society Special Publication, 352, 1-9.

Witte, L. (1916). Estudios geológicos de la región de San Blas (Partido de Patagones). Revista del Museo de La Plata, 24, 7-99.

Woodward, J. (2011). Scientific explanation. In E. N. Zalta (Ed.), The Stanford encyclopedia of philosophy (Winter 2011 Edition). http://plato.stanford.edu/archives/win2011/entries/scientific-explanation/. Accessed 20 Mar 2013.

Zubrow, E. B. W., \& Harbaugh, J. W. (1978). Archaeological prospecting: kriging and simulation. In I. Hodder (Ed.), Simulation studies in archaeology (pp. 109-122). Cambridge: Cambridge University Press.

Zvelebil, M., Green, S. W., \& Mackiln, M. G. (1992). Achaeological landscapes, lithic scatters and human behavior. In J. Rossignol \& L. Wandsnider (Eds.), Space, time and archaeological landscapes (pp. 193226). New York: Plenum. 